\title{
Impact of COVID-19 on the Air Quality over China and India Using Long-term (2009-2020) Multi- satellite Data
}

Special Issue:

Special Issue on COVID-19 Aerosol Drivers, Impacts and Mitigation (XI)

\section{Manish Soni ${ }^{1}$, Sunita Verma ${ }^{2,3^{*}}$, Hiren Jethava ${ }^{4}$, Swagata Payra ${ }^{1}$, Lok Lamsal ${ }^{4}$, Priyanshu Gupta ${ }^{2}$, Janhavi Singh ${ }^{2}$}

${ }^{1}$ Department of Physics, Birla Institute of Technology Mesra, Jaipur Campus, Jaipur-302017, Rajasthan, India

${ }^{2}$ Institute of Environment and Sustainable Development, Banaras Hindu University, Varanasi221005, Uttar Pradesh, India

${ }^{3}$ DST-Mahamana Centre of Excellence in Climate Change Research, Banaras Hindu University, Varanasi-221005, Uttar Pradesh, India

${ }^{4}$ Goddard Earth Sciences Technology and Research, Universities Space Research Association, Columbia, MD, USA

\section{ABSTRACT}

We have examined the air quality over China, India and demonstrated marked differences in levels of air pollution resulted from the COVID-19 restrictions during December-April, 2019-20 to that of 11 years mean of 2009-19. The criteria air quality indicators i.e., nitrogen dioxide $\left(\mathrm{NO}_{2}\right)$, sulphur dioxide $\left(\mathrm{SO}_{2}\right)$, Aerosol Index ( $\mathrm{Al}$ ) and aerosol optical depth (AOD) data are retrieved from the Ozone Monitoring Instrument (OMI), TROPOspheric Monitoring Instrument (TROPOMI), and MODerate Resolution Imaging Spectroradiometer (MODIS) sensor on the Terra and Aqua satellites, respectively. Over China, during COVID-19 lockdown a significant drop in columnar abundances of tropospheric $\mathrm{NO}_{2}(-37 \%), \mathrm{SO}_{2}(-64 \%)$ and $\mathrm{AOD}(-8 \%)$ for 2020 in comparison to 11 years mean (2009-19) has been observed. A noticeable difference in $\mathrm{NO}_{2}$ column burden is seen over SE (-35\%), NE (-33\%), NW (-13\%) and SW (-5\%) China. Over the SE and NE China, both $\mathrm{NO}_{2}$ and $\mathrm{SO}_{2}$ levels decreased dramatically in 2020 from that of 2009-19, by more than $40 \%$ and $65 \%$, respectively, because of both stricter regulations of emissions and less traffic activity due to reduced social and industrial activities during COVID-19 restrictions. In contrast, the curve of monthly mean tropospheric columnar burden of $\mathrm{NO}_{2}$ and $\mathrm{SO}_{2}$ over India has shown moderate reduction of $16 \%$ and $20 \%$, respectively because lockdown came into effect much later in March 2020. The mean $\mathrm{NO}_{2}$ and $\mathrm{SO}_{2}$ over IGP region is found to be $25 \%$ higher than whole India's mean concentration due to large scale urban settlement and crop burning events. The statistical t-test analysis results confirm significant $(p<0.05$ ) improvements in AQ during lockdown. The COVID19 pandemic provided an unprecedented opportunity to investigate such large-scale reduction in emissions of trace gases and aerosols. Therefore, it is important to further strengthen environmental policies to tackle air quality, human health, and climate change in this part of the world.

Keywords: OMI, MODIS, $\mathrm{NO}_{2}, \mathrm{SO}_{2}, \mathrm{AOD}$, COVID-19, Air quality, Aerosol index, t-test

\section{INTRODUCTION}

On $31^{\text {st }}$ December 2019, pneumonia of unknown origins first detected in Wuhan city of Hubei province of China reported to the World Health Organization (WHO, 2020). Days later, researchers confirmed a disease of severe acute respiratory syndrome caused by novel coronavirus-2 (SARSCoV-2) is spreading via respiratory droplets produced during coughing (Andersen et al., 2020; 
CDC Situation Summary, March 21, 2020; Gorbalenya et al., 2020). These single stranded Ribonucleic Acid (RNA) viruses with a lipoprotein envelope have the same epidemic properties as influenza viruses (Robson, 2020). The disease named as coronavirus disease 2019 or COVID19 and declared a pandemic by WHO on 11 March 2020 (WHO, 2020a). Fever and cough are the common symptoms of SARS-CoV-2 affected patient. Involvement of bilateral lung with ground glass opacity is the most common finding of computed tomography images (Lai et al., 2020). In the early stage of the outbreak, patients in Wuhan, China had demonstrated association to a huge live animal and seafood market, pointing towards animal-to-person transmission (Andersen et al., 2020; CDC Situation Summary, 2020; Lai et al., 2020; Wu et al., 2020; Zhou et al., 2020). However, in the later stage, cases of COVID-19 were drastically increasing, and the patients reportedly did not have any exposure to animal markets, indicative of person-to-person transmission (Carlos et al., 2020; Li et al., 2020; Wang et al., 2020c). Person-to-person transmission successively appeared outside Hubei Province and in countries outside China, including Italy, Spain, the United States of America, Iran, Republic of Korea, etc. With a death toll of 217,769 people reported across the globe as per WHO (updated on $30^{\text {th }}$ April 2020; WHO, 2020d), untold socio-economic disruptions and increasing lockdowns, the COVID-19 has now transformed into a global catastrophe. A number of factors, including population density, medical care quality and climatic conditions such as temperature and humidity (Hemmes et al., 1960; Dalziel et al., 2018; Wang et al., 2020a) can affect transmission of viruses.

After H1N1 (2009), polio (2014), Ebola in West Africa (2014), Zika (2016) and Ebola in the Democratic Republic of Congo (2019), on $30^{\text {th }}$ January 2020, COVID-19 outbreak declared as the sixth public health emergency of international concern by WHO on 20 January, 2020. Therefore, this global concern needs the cooperation of health workers, public, and governments to prevent its spread at global level (Yoo, 2020).

Different regions of the world are experiencing varying levels of COVID-19 exposure. Worldwide cases and community spread in a growing number of countries have detected. As of 11th February 2020, WHO recorded 43,103 confirmed cases of COVID-19 (WHO, 2020c) but this increases steadily not only in the China but also in rest of the world. As of $30^{\text {th }}$ April 2020 , a total of 30,90445 confirmed cases were reported from 209 regions of the world which includes countries, areas and territories (WHO, 2020d). Fig. 1 represents the latest global distribution of confirmed cases of COVID-19 until 23-30 April 2020. Two of the major regions of the world affected by this pandemic after China are the European Nations (especially Italy, Spain) and the United States of America. The spread of SARS-CoV-2 has amplified by many-folds in the past two months. Staring from only 7 cases reported on 22 January 2020, the disease spread underwent a skyrocketing increase with a total of 3 million confirmed cases (WHO, 2020d).

\subsection{Rationale}

Due to unprecedented nature of COVID-19, each country has adopted different measures like social distancing, travel restrictions, complete or partial lockdown etc because of different level of impacts. The process of lockdown first started in Wuhan, China on $23^{\text {rd }}$ January 2020 where the first case has reported. The process includes movement, shutting down of businesses, industrial activities etc (Jing, 2020). India, the second most populated country after China due to increasing cases of COVID-19 also started a completed lockdown from 25 $5^{\text {th }}$ March 2020 (Chandrashekhar, 2020). The same procedures then adopted by several countries. This unprecedented measures and lockdown imposed by several nations to stop the spread of COVID-19 have notable impact on the environment, in the form of a significant drop in air pollutant levels due to restrictions in all forms of transport (flights, train, and automobiles), factories, shops, markets, shopping malls, traffic, social and economic activities.

In course of the COVID-19 pandemic throughout lockdown episode, noteworthy improvements in the ambient air quality have been reported in several parts of the world (Nakada and Urban, 2020; Tobías et al., 2020; Watts and Kommenda, 2020; Zalakeviciute et al., 2020, etc.). Up-todate several attempts have been made to report the unexpected impact of COVID-19 lockdown on the air quality over China (Chen et al., 2020; Filonchyk et al., 2020; Zhang et al., 2020) and India (Bera et al., 2020; Gautam, 2020; Jain and Sharma, 2020; Mahato and Ghosh, 2020; Ranjan et al., 2020; Sharma et al., 2020; Singh and Chauhan, 2020). Few simulation studies have also assessed the lockdown-induced changes in the ambient air quality and associated role of 


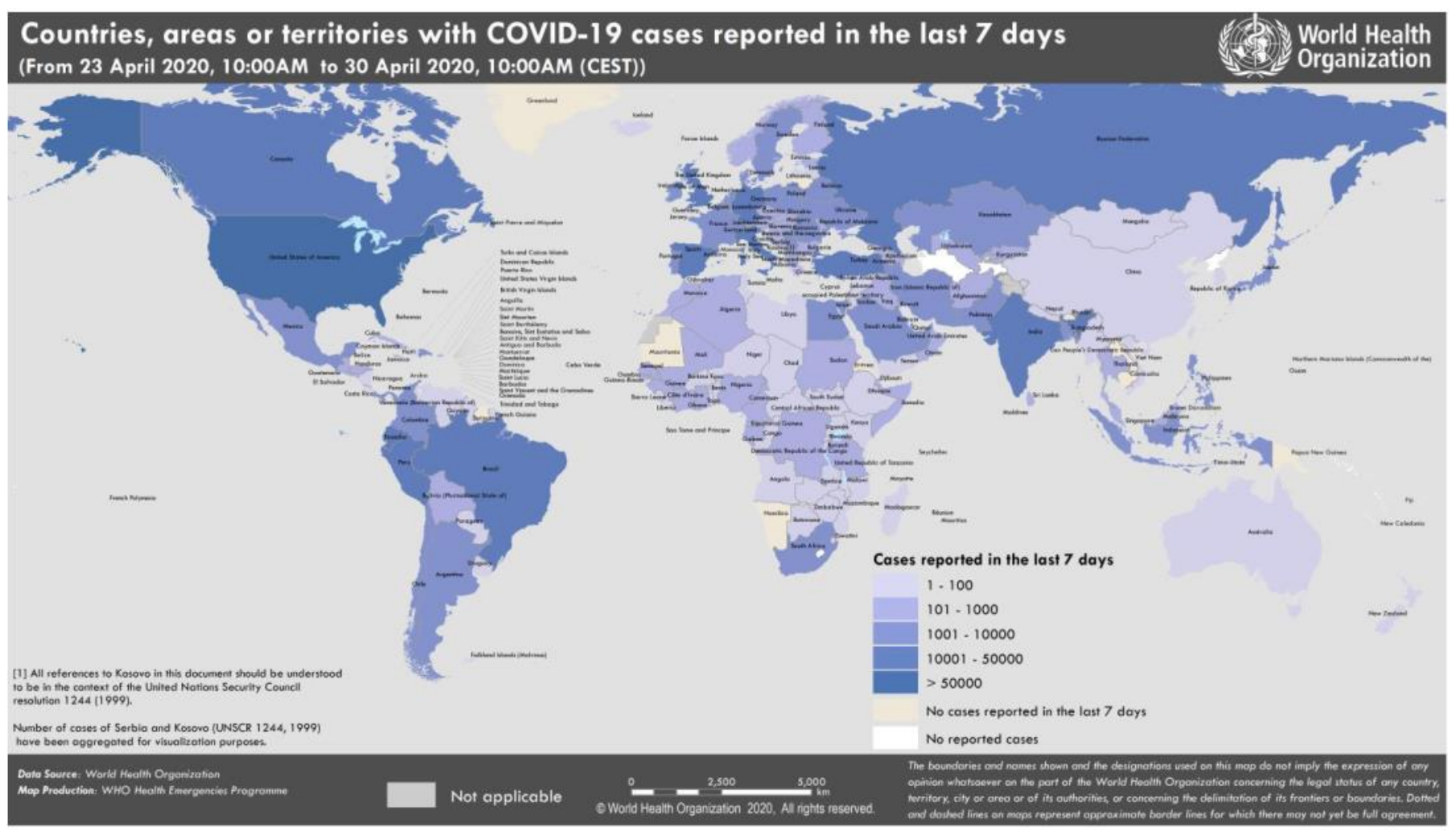

Fig. 1. Global Distribution of COVID-19 cases all over the world during $23^{\text {th }}$ April 2020 to $30^{\text {th }}$ April 2020. *Source: Coronavirus disease 2019 (COVID-19) Situation Report-101 (WHO, 2020d).

meteorological parameters (Le et al., 2020; Sharma et al., 2020; Wang et al., 2020b). For the Indian region, the studies are primarily focused on the urban regions and reported improvement of air quality with significant decline in indicators namely $\mathrm{NO}_{2}$ and $\mathrm{PM}_{2.5}$ concentrations amid the lockdown period (Bera et al., 2020; Jain and Sharma 2020; Mahato and Ghosh, 2020; Sharma et al., 2020; Singh and Chauhan, 2020).

Majority of the aforementioned studies depicted an improvement in the air quality over part of China or India, but the extent up to which these improvements actually holds valid needs an in-depth investigation. In order to gain better insight on the impact of COVID-19 lockdown on air quality status, a considerably long-term pollution dataset needs to be compared with that of the lockdown duration of 2020 and is a major shortcoming in most of such recent studies.

Thus, this is possibly, the first study where long-term (2009-2019) satellite observations of four major ambient air quality criteria indicators namely $\mathrm{NO}_{2}, \mathrm{SO}_{2}, \mathrm{AOD}$ and Aerosol Index are retrieved and systematically analysed for the entire South-East Asian region with special emphasis on China and India during lockdown period. The present study includes a climatological period encompassing December to April of 11 years (2009-2019) prior to the coronavirus as a reference state with that of coronavirus outbreak during December-April, 2019-20. Additionally, the current study analysed the hotspots regions (higher concentration) for $\mathrm{NO}_{2}, \mathrm{SO}_{2}$, $\mathrm{Al}$ and $\mathrm{AOD}$ for both China (NW and SW) and India (IGP region), thereby presenting a better comparative view on the COVID-19 lockdown induced air quality changes over these nations.

The objective of present research work is therefore to examine and quantify the effect of COVID-19 outbreak and restrictions on the air quality over China and India in terms of ambient pollution levels. For this, the criteria air quality indicators i.e., nitrogen dioxide $\left(\mathrm{NO}_{2}\right)$, sulphur dioxide $\left(\mathrm{SO}_{2}\right)$, Aerosol Index (Al) and aerosol optical depth (AOD) for year 2020 has been compared with mean of 2009-19 using the data from Ozone Monitoring Instrument (OMI), TROPOspheric Monitoring Instrument (TROPOMI), and MODerate Resolution Imaging Spectroradiometer (MODIS) sensor on the Terra and Aqua satellites, respectively. 


\section{DATA AND METHODS}

Fig. 2 shows the selected spatial domain spanning over latitudes ranging from $10^{\circ} \mathrm{S}$ to $60^{\circ} \mathrm{N}$ and longitude range of $60^{\circ} \mathrm{E}$ to $140^{\circ} \mathrm{E}$ and covers the Eastern and South Asian region. The study focuses majorly over China and India, together constituting the largest portion of the domain coverage area.

The severity of COVID-19 spread over the study domain is like that in Asia the highest number of confirmed cases were reported were from China (84373) followed by India (33050), Republic of Korea (10765) and then Malaysia (5945). At the time of preparing this article, India was undergoing Phase-2 outbreak of the coronavirus disease with a total fatalities' of 1074 deaths (dated as of $30^{\text {th }}$ April 2020).

\section{SATELLITE DATA DESCRIPTION}

\subsection{Ozone Monitoring Instrument (OMI)}

The OMI onboard NASA's Aura satellite is a nadir-viewing spectrograph, measuring the atmosphere-backscattered and direct sunlight in the ultraviolet-visible (UV-VIS) region (Levelt et al., 2006). The Aura satellite launched in July 2004 is a sun-synchronous polar orbit satellite flying in formation with A-train constellation with an equator crossing time of about 13:45 local time. With a spatial swath of $2600 \mathrm{~km}$ on ground, it provides global coverage in one day.

The daily coverage and nadir pixel size of $13 \mathrm{~km} \times 24 \mathrm{~km}$ (along track $\times$ across track) and spectral resolution between $0.42 \mathrm{~nm}$ and $0.63 \mathrm{~nm}$ enables $\mathrm{OMI}$ as one of the best instruments to observe different sources of air pollution (Boersma et al., 2008). Measurement of radiometric stability of OMI have been confirmed by regular evaluation of sensitivity changes (Dobber et al., 2008; Marchenko and DeLand, 2014; Schenkeveld et al., 2017). A detailed description related with instrument calibration have reported before (Dobber et al., 2005, 2006).

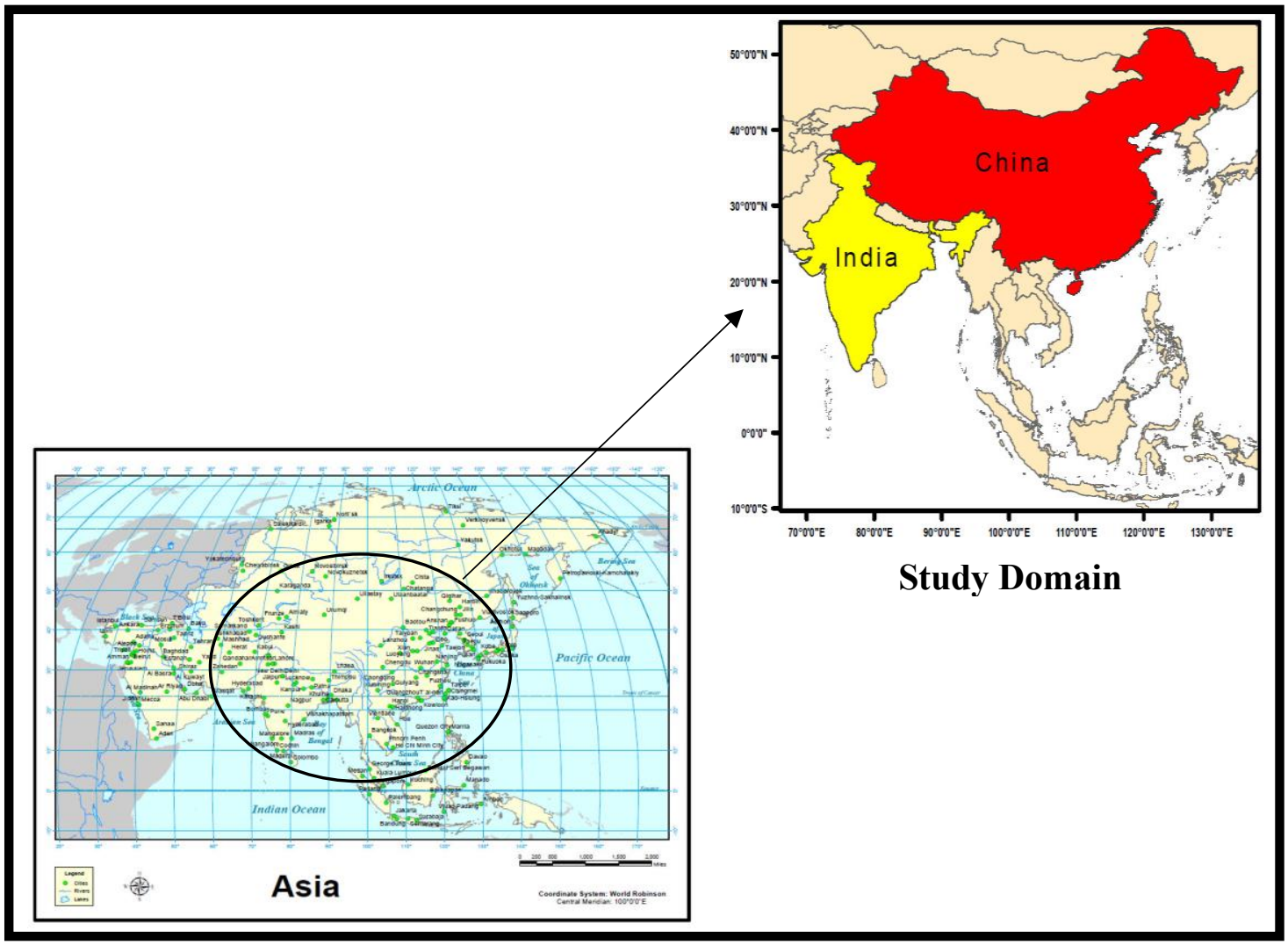

Fig. 2. Study Domain selected for the present analysis i.e., China and India. 
OMI measurements allow retrieval of column amount of ozone, and of other trace gases related to photochemical smog production and air pollution, i.e., $\mathrm{SO}_{2}$ (e.g., Li et al., 2013), $\mathrm{NO}_{2}$ (e.g., Boersma et al., 2011; Bucsela et al., 2013; Lamsal et al., 2014), and HCHO (e.g., Kurosu et al., 2004). In addition, it also provides observations of aerosol characteristics, UV irradiance at the surface, and cloud top heights. In relation to retrieval requirements, the detailed description of OMI instruments is discussed (Levelt et al., 2018).

For this study, we have used the latest version of tropospheric column density of $\mathrm{NO}_{2}$ from Level-3 $\left(0.25^{\circ} \times 0.25^{\circ}\right)$ gridded product (Krotkov et al., 2019) and total vertical column density of $\mathrm{SO}_{2}$ from the operational Level-3 $\left(0.25^{\circ} \times 0.25^{\circ}\right)$ gridded planetary boundary layer $(\mathrm{PBL})$ product (Krotkov et al., 2015). The OMI retrieved $\mathrm{NO}_{2}$ contains the vertical column density data for clearsky conditions with effective cloud fraction less than 30 percent.

\subsection{TROPOspheric Monitoring Instrument Aerosol Index (AI)}

TROPOMI onboard the Sentinel-5P uses push broom technique to measure the OMI chosen $354 / 388 \mathrm{~nm}$ pair to calculate the UV Aerosol Index (Copernicus Sentinel-5P (processed by ESA), 2018). It has $108^{\circ}$ field of view and also provides measurements of ozone, $\mathrm{NO}_{2}, \mathrm{SO}_{2}, \mathrm{CH}_{4}, \mathrm{CO}$, formaldehyde, aerosols and cloud at high spatial, temporal and spectral resolutions (https://disc.gsfc.nasa.gov/datasets/S5P_L2__AER_Al_1/summary).

Since, the UV Aerosol Index (AI) data from the OMAERUV (version 1.8.9.1) aerosol product suffers row anomaly problem sometimes so we have used Sentinel-5 Precursor (Sentinel-5P or S5P) TROPOMI UV Aerosol Index calculated on the OMI chosen 354/388 nm pair level 2.0 data to study the changes in aerosol patterns during the study period. It is having spatial resolution of $7 \mathrm{~km} \times 3.5 \mathrm{~km}$. The data is available from $28^{\text {th }}$ June 2018 to current date. In the present study, we have compared 2019 UV Aerosol index with 2020 for the same time.

\subsection{Moderate Resolution Imaging Spectroradiometer (MODIS)}

MODIS measures the columnar light extinction by aerosol particles during satellite overpass time and represents the columnar optical properties. AOD is a crucial parameter to estimate air quality. The level 3.0 collection version 6.1 monthly mean AOD data at $550 \mathrm{~nm}$ wavelength is extracted from MODIS for the study period (Payra et al., 2015; Kang et al., 2016). More details about the retrieval techniques and concepts can be found elsewhere (Levy et al., 2013). Terra and Aqua pass at 10:30 am and 01:30 pm equator crossing time during daytime. There are two MODIS monthly global data product files: MOD08_M3, containing data collected from the Terra platform; and MYD08_M3, containing data collected from the Aqua platform. Statistics are sorted into $1^{\circ} \times 1^{\circ}$ degree cells on an equal-angle grid that spans a (calendar) monthly interval and then summarized over the globe. Both Terra and Aqua retrieved AOD are combined to form mean AOD over the study domain.

For evaluating the daily variations in AOD, MCD19A2, a combined product of MODIS level-2 collection version 6.0 gridded data over land surfaces has been extracted. A product i.e., MCD19A2 is short name of Multi-Angle Implementation of Atmospheric Correction (MAIAC) algorithm and is available daily at $1 \mathrm{~km}$ pixel resolution a much finer resolution. It is multi-layer scientific dataset containing the AOD at $470 \mathrm{~nm}$ in blue band and AOD at $550 \mathrm{~nm}$ in green band. It also generates other aerosol properties like fine mode fraction over water, column water vapour over land and clouds (in $\mathrm{cm}$ ), smoke injection height ( $\mathrm{m}$ above ground) etc. The current study covers 11 years mean of December-April, 2009-19 and 2020.

Daily satellite observations for study domain with the specified latitude and longitude, as shown in Fig. 2, to develop an understanding about the temporal changes in $\mathrm{NO}_{2}, \mathrm{SO}_{2}$, Aerosol Index and AOD amounts during the 2009-2020 period are extracted.

\section{RESULTS AND DISCUSSIONS}

To systematically investigate the changes in air quality over South-East Asia, we analyse the spatial distribution and temporal changes $\mathrm{NO}_{2}, \mathrm{SO}_{2}$, and $\mathrm{AOD}$ for January, February, March and April month of year 2020 and 11 years mean of 2009-19. For Al, the comparison has been done only with 2019 data. Throughout the paper, the lockdown period over China from $23^{\text {rd }}$ January 
to $08^{\text {th }}$ April 2020 is considered. The lockdown over India from $25^{\text {th }}$ March to $30^{\text {th }}$ April 2020 (COVID-19 Situation Report-101, 2020) is considered. The paper also analyses and compares the hotspots regions (higher concentration) for $\mathrm{NO}_{2}, \mathrm{SO}_{2}, \mathrm{Al}$ and $\mathrm{AOD}$ for both China and India.

\subsection{Variation in $\mathrm{NO}_{2}$ Concentration over China}

Aura OMI $\mathrm{NO}_{2}$ column densities have been utilized as an indicator for $\mathrm{NO}_{\mathrm{x}}$, relationships between air quality and imposed restriction during COVID-19 over region of study. The emissions of $\mathrm{NO}_{x}$ generally result from road traffic (Kendrick et al., 2015) and other fossil fuel combustion and natural (e.g., lightning) processes. When this pollutant is more it can reduce the immunity to lung infection and can results into respiratory problems. In this section, $\mathrm{NO}_{2}$ columnar concentration are investigated over China and India with differences observed between January-April, 2009-19 and January-April 2020.

Figs. 3(a)-3(d) shows the tropospheric $\mathrm{NO}_{2}$ column over study domain. The columns show 2020 (left), 2009-19 (middle), and the percentage change between 2020 and 2009-19 (right) while individual rows show different months i.e., (a) January (b), February (c) March (d) April, respectively.

During coronavirus outbreak, China enforced lockdown and restrictions from $23^{\text {rd }}$ January to $08^{\text {th }}$ April 2020. The effect of restrictions during coronavirus outbreak on tropospheric $\mathrm{NO}_{2}$ columnar burden has been analysed by estimating percentage change in average $\mathrm{NO}_{2}$ for lockdown period i.e., $23^{\text {rd }}$ Jan- $08^{\text {th }}$ April, $2020\left\{\mathrm{NO}_{2(2020)}\right\}$ with that of 11 years mean of $23^{\text {rd }}$ Jan$08^{\text {th }}$ April, 2009-19 $\left\{\mathrm{NO}_{2(2009-19)}\right\}$.

(a)

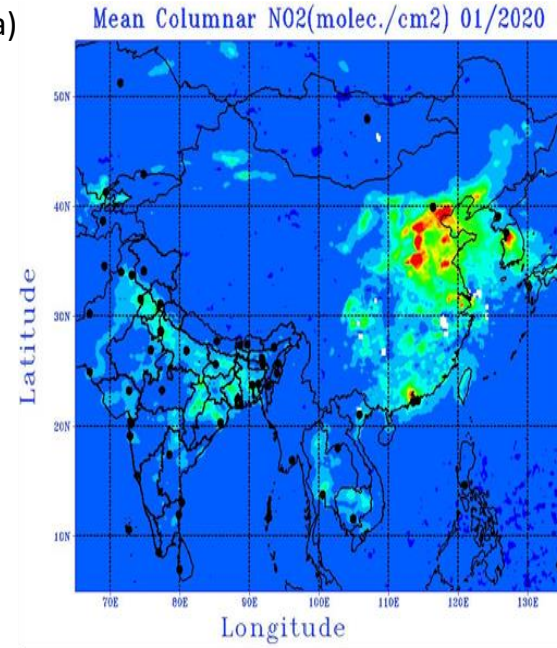

(b)

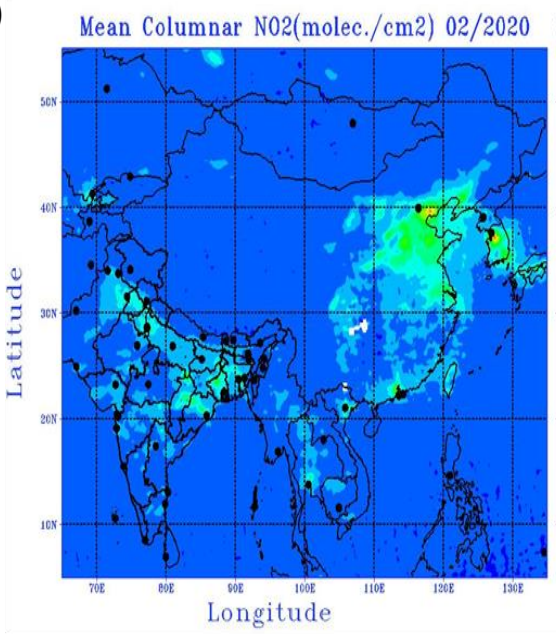

Mean Columnar N02(molec./cm2) 01/2009-19

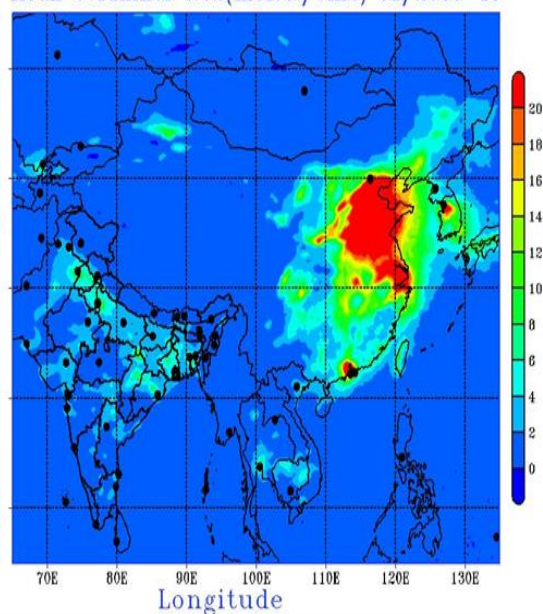

Mean Columnar N02(molec./cm2) 02/2009-19

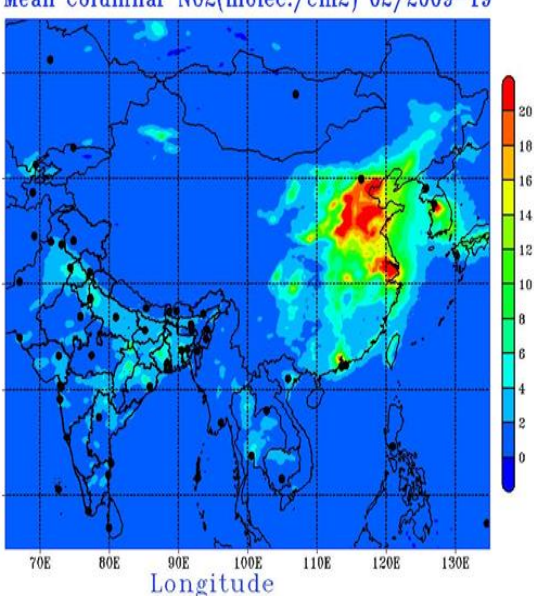

\%Change N02(molec./cm2) 01/2020 minus 01/2009-19

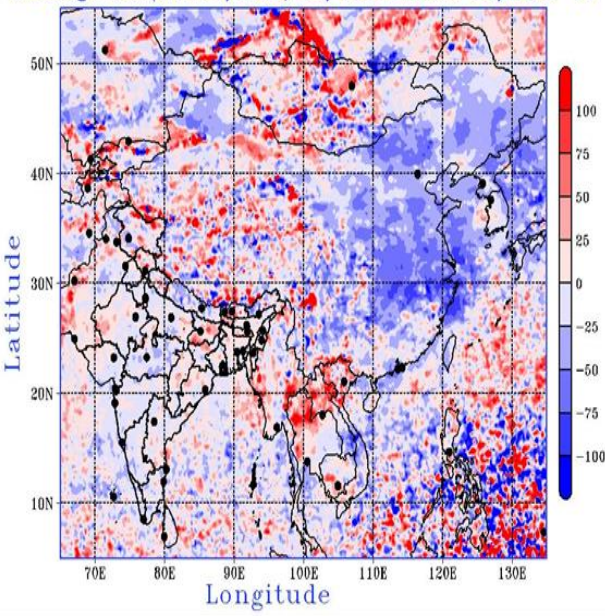

\%Change NO2(molec/cm2) 02/2020 minus $02 / 2009-19$

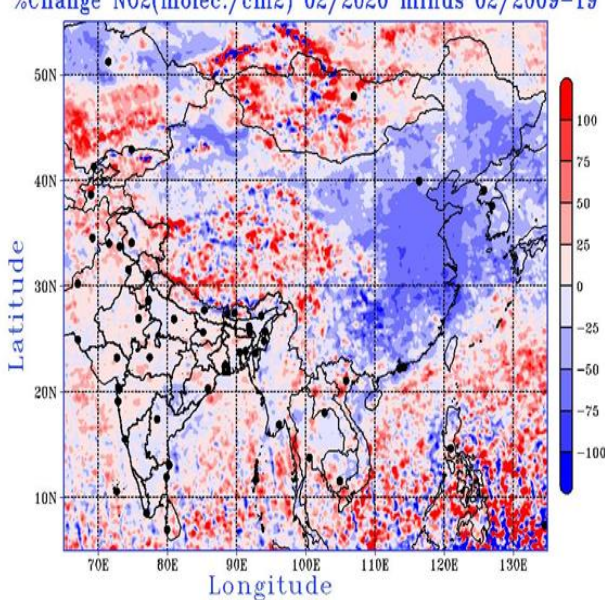

Fig. 3. OMI retrieved column density $\mathrm{NO}_{2}$ during (a) January, (b) February (c) March, and (d) April for 2020 (left panel), $2009-19$ (middle panel) and Percentage Change in right panel. All these figures are having scaling factor of $1 \times 10^{15} \mathrm{molec} . \mathrm{cm}^{-2}$. 
(c)

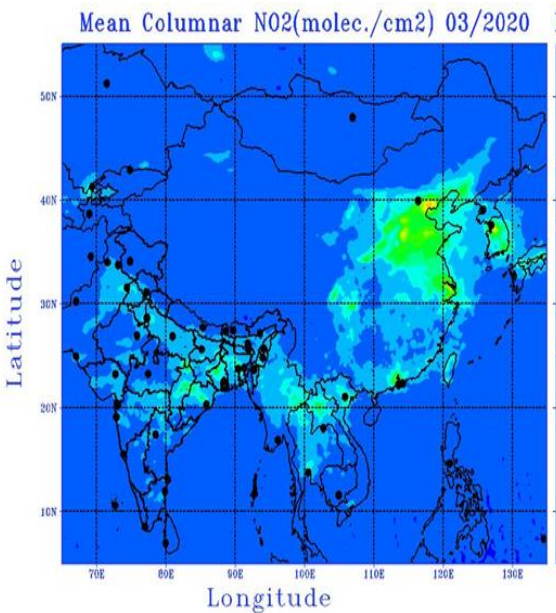

(d)

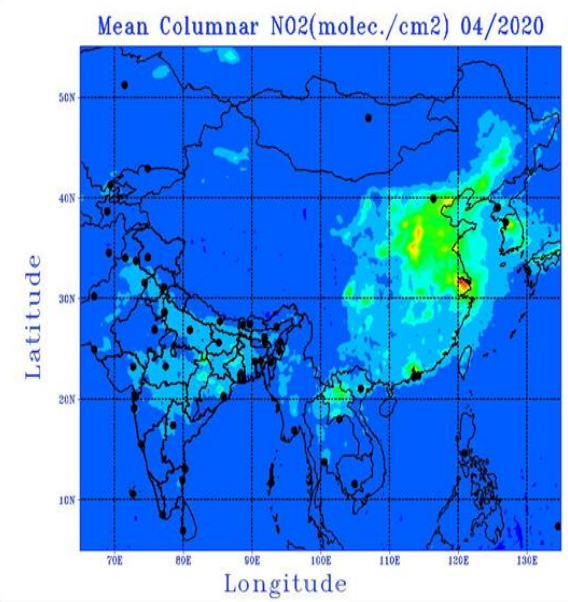

Mean Columnar N02(molec./cm2) 03/2009-19

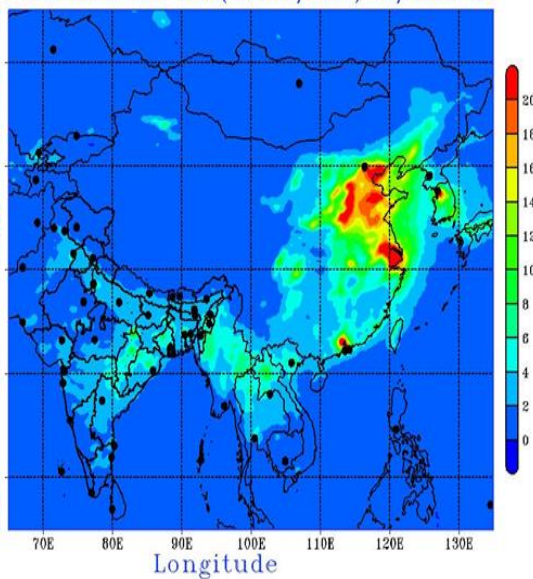

Mean Columnar N02(molec./cm2) 04/2009-19

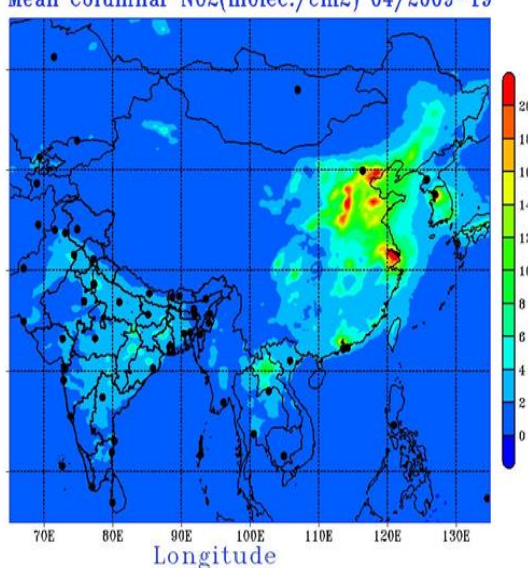

\%Change N02(molec./cm2) 03/2020 minus 03/2009-19

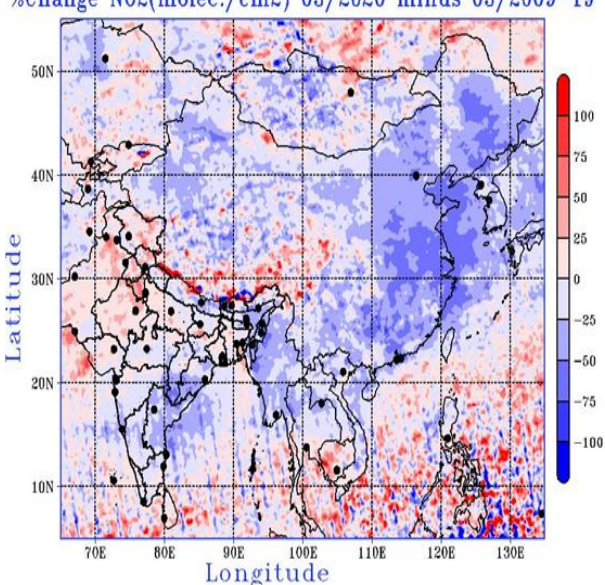

\%Change N02(molec./cm2) 04/2020 minus 04/2009-19

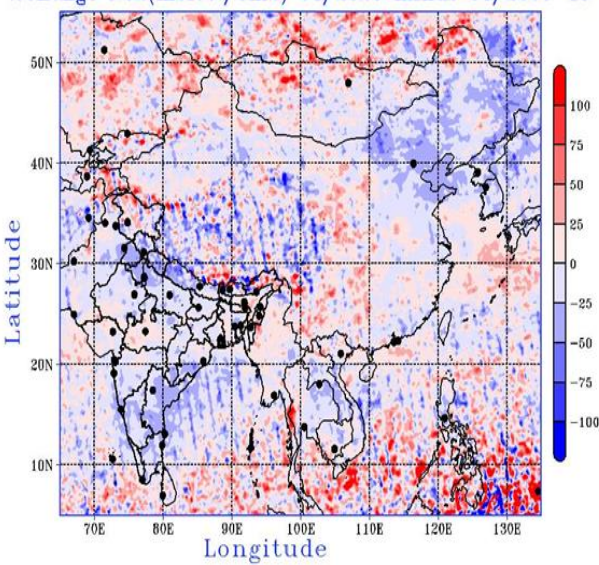

Fig. 3. (continued).

The validation of the $\mathrm{OMI}-\mathrm{NO}_{2}$ with ground and aircraft measurements have been done in previous studies (Boersma et al., 2008; Boersma et al., 2011; Bucsela et al., 2013; Lamsal et al., 2014). A good agreement between the tropospheric $\mathrm{OMI}-\mathrm{NO}_{2}$ column and ground-based measurements have been shown. The monthly tropospheric $\mathrm{NO}_{2}$ column of 11 years mean for 2009-19 are found to be $2.86 \pm 0.23 \times 10^{15}, 2.3 \pm 0.31 \times 10^{15}, 2.6 \pm 0.37 \times 10^{15}$ and $2.47 \pm 0.43 \times 10^{15}$ molec. $\mathrm{cm}^{-2}$ during January, February, March and April, respectively.

On the contrary, much lesser quantity of monthly mean $\mathrm{NO}_{2}$ columnar burden are observed during $1.09 \pm 0.54 \times 10^{15}$ in January, $1.17 \pm 0.40 \times 10^{15}$ in February, $1.96 \pm 0.64 \times 10^{15}$ in March, and $2.09 \pm 0.34 \times 10^{15}$ molec. $\mathrm{cm}^{-2}$ in April, 2020, respectively. The above value shows mean \pm standard deviation. During the lockdown (23rd Jan-8th April) period, the mean tropospheric $\mathrm{NO}_{2}$ column of $2.51 \pm 0.39 \times 10^{15}$ molec. $\mathrm{cm}^{-2}$ and $1.58 \pm 0.67 \times 10^{15}$ molec. $\mathrm{cm}^{-2}$ are observed for 200919 and 2020, respectively. Hence, the lockdown due to COVID-19 pandemic has shown intense effect on tropospheric columnar burden of $\mathrm{NO}_{2}(2020)$ with that of $\mathrm{NO}_{2}(2009-19)$ resulting in drop by around $37 \%$ over China.

For determination of characteristics effect of lockdown on $\mathrm{NO}_{2}$ density over China, the time series of averaged daily tropospheric $\mathrm{NO}_{2}$ columnar values (Fig. 4) has been analysed for 2020 and 11 years mean for 2009-19. The time series graph depicts large decrease $(\approx 30 \%)$ in $\mathrm{NO}_{2}$ emissions during February 2020 in comparison to January 2020 as well as 2009-19. Evidently, the spatial plots also depict similar pronounced effects during February and March (Figs. 3(b) and 3 (c)) months in tropospheric $\mathrm{NO}_{2}$ column during peak lockdown measures over China where $\mathrm{NO}_{2}$ values in NE and SE China shows a maximum decrease than normal observation for this period. This positive trend during $2009-19$ is quite reliable with the trend (1.76 $\pm 1.1 \%$ per year) reported before by Ghude et al. (2008) for the same study region. This trend is also consistent with the restrictions of traffic during COVID-19 over China. 


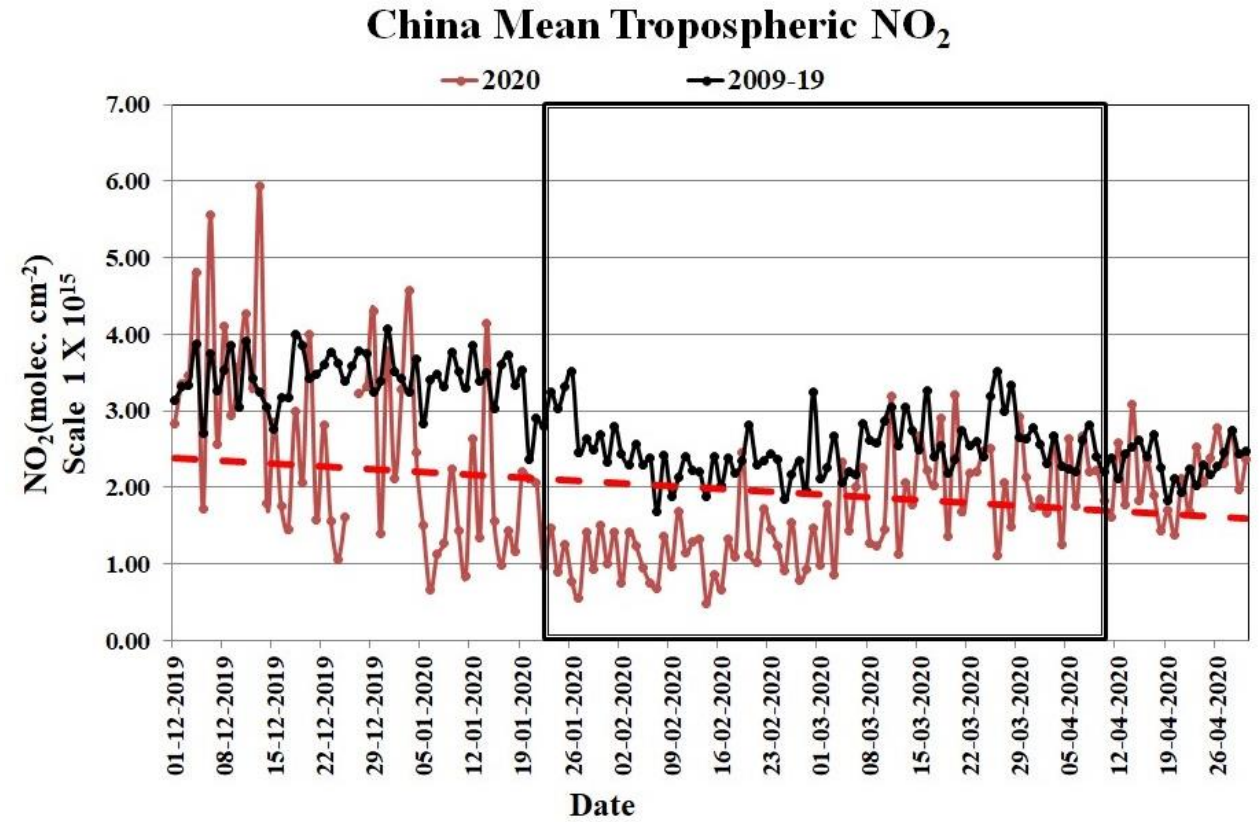

Fig. 4. Time series of area averaged values (December-April) of $\mathrm{NO}_{2}$ column density for 2009-19 (black) and 2020 (Red) for China. The black rectangle shows the period of lockdown i.e., $23^{\text {rd }}$ January 2020 to $08^{\text {th }}$ April 2020. Red dash line shows trend line during Dec-April, 2020.

A further analysis on $\mathrm{NO}_{2}$ column burden is conducted by dividing China into four extensive physical sub-regions: North East (NE), South East (SE), North West (NW) and South West (SW) China. Table 1 shows the part-wise distribution of $\mathrm{NO}_{2}$ columnar burden. The major provinces in $\mathrm{NE}\left(36^{\circ} \mathrm{N}-54^{\circ} \mathrm{N}, 104^{\circ} \mathrm{E}-136^{\circ} \mathrm{E}\right)$ China are Beijing, Hebei, Jilin, Shandong etc.

The NW $\left(36^{\circ} \mathrm{N}-54^{\circ} \mathrm{N}, 72^{\circ} \mathrm{E}-104^{\circ} \mathrm{E}\right)$ and $\mathrm{SW}\left(18^{\circ} \mathrm{N}-36^{\circ} \mathrm{N}, 72^{\circ} \mathrm{E}-104^{\circ} \mathrm{E}\right)$, China are sparsely populated and comprises of Tibet Sichuan Xinjiang, Qinghai etc. The major provinces over SE $\left(18^{\circ} \mathrm{N}-36^{\circ} \mathrm{N}, 104^{\circ} \mathrm{E}-136^{\circ} \mathrm{E}\right)$ China are Guangdong, Guangxi, Yunnan etc. The descriptive analysis in Table 1 shows a noticeable difference in mean (January-April) $\mathrm{NO}_{2}$ with a percentage change of $-35,-33,-13$ and $-5 \%$, over SE, NE, NW and SW China, respectively. The COVID-19 pandemic has shown maximum reduction in $\mathrm{NO}_{2}$ columnar burden over SE (58\%) and $\mathrm{NE} \mathrm{(47 \% )} \mathrm{part} \mathrm{of} \mathrm{China}$ during month of February 2020. Xu et al. (2020) also reported the reduction in $\mathrm{NO}_{2}$ concentrations in three cities in Hubei Province, Wuhan, Jingmen, and Enshi in central China by more than 50\% during February month. These cities come under SE China as per our classification. This also verifies our results.

Overall, during lockdown i.e., $23^{\text {rd }}$ Jan $-8^{\text {th }}$ April period, a significant drop of around $42 \%$ and $32 \%$ has been observed in tropospheric columnar burden of $\mathrm{NO}_{2(2020)}$ with that of $\mathrm{NO}_{2(2009-19)}$ columnar burden over SE and NE China, respectively. Filonchyk et al. (2020) suggested that there is $30 \%$ reduction in Eastern China during the lockdown. The results agree with NE China percentage changes $(\approx 33 \%)$ which covers most of the eastern China.

The increase in anthropogenic emissions due to traffic, increasing power generation, flourishing industries, rapid urbanization, more demand of agricultural products, and more biomass fuel usage are the primary sources of $\mathrm{NO}_{2}$ over China and India. The significant percentage decrease in the mean concentration of $\mathrm{NO}_{2}$ is predominantly due to the decrease in traffic and 'startstop' action of vehicular movements. Besides this, the enhanced pollutant emissions due to industrial emissions are probable reasons for increase in $\mathrm{NO}_{2}$ over China, which was severely under control due to lockdown.

\subsection{Variation in $\mathrm{NO}_{2}$ Concentration over India}

Unlike China, $\mathrm{NO}_{2}$ over India (Figs. 3 and 5) has not changed as that of China with a specific negative trend in $\mathrm{NO}_{2}$ over time. The not so considerate difference in tropospheric $\mathrm{NO}_{2}$ column over India which could be attributed due to restrictions imposed on a much later date (i.e., $25^{\text {th }}$ March, 
Table 1. Monthly mean tropospheric $\mathrm{NO}_{2}$ column density over $\mathrm{NE}, \mathrm{NW}, \mathrm{SW}, \mathrm{SE}$ part of China. Values in the brackets shows percentage change.

\begin{tabular}{lllllllll}
\hline Month & 2009-19_SW & 2020_SW & 2009-19_NW & 2020_NW & 2009-19_SE & 2020_SE & 2009-19_NE & 2020_NE \\
\hline January & 0.31 & $0.25(-18.02)$ & 0.70 & $0.59(-16.21)$ & 10.73 & $4.68(-56.35)$ & 4.98 & $2.77(-44.36)$ \\
February & 0.34 & $0.31(-8.44)$ & 0.60 & $0.44(-26.63)$ & 7.13 & $2.98(-58.22)$ & 3.61 & $1.92(-46.79)$ \\
March & 0.61 & $0.73(19.18)$ & 0.67 & $0.64(-3.91)$ & 7.24 & $5.17(-28.66)$ & 4.01 & $3.12(-22.26)$ \\
April & 0.51 & $0.45(-12.77)$ & 0.74 & $0.7(-5.63)$ & 5.27 & $5.36(1.71)$ & 3.93 & $3.17(-19.28)$ \\
\hline
\end{tabular}

Maximum reduction in $\mathrm{NO}_{2}$ columnar burden is seen in $\mathrm{SE}(35 \%)$ and $\mathrm{NE}(33 \%)$ China. Maximum reduction is seen during February month for all four parts of China categorized. SE (-58\%) and NE (-46\%) China suffers maximum change during February.

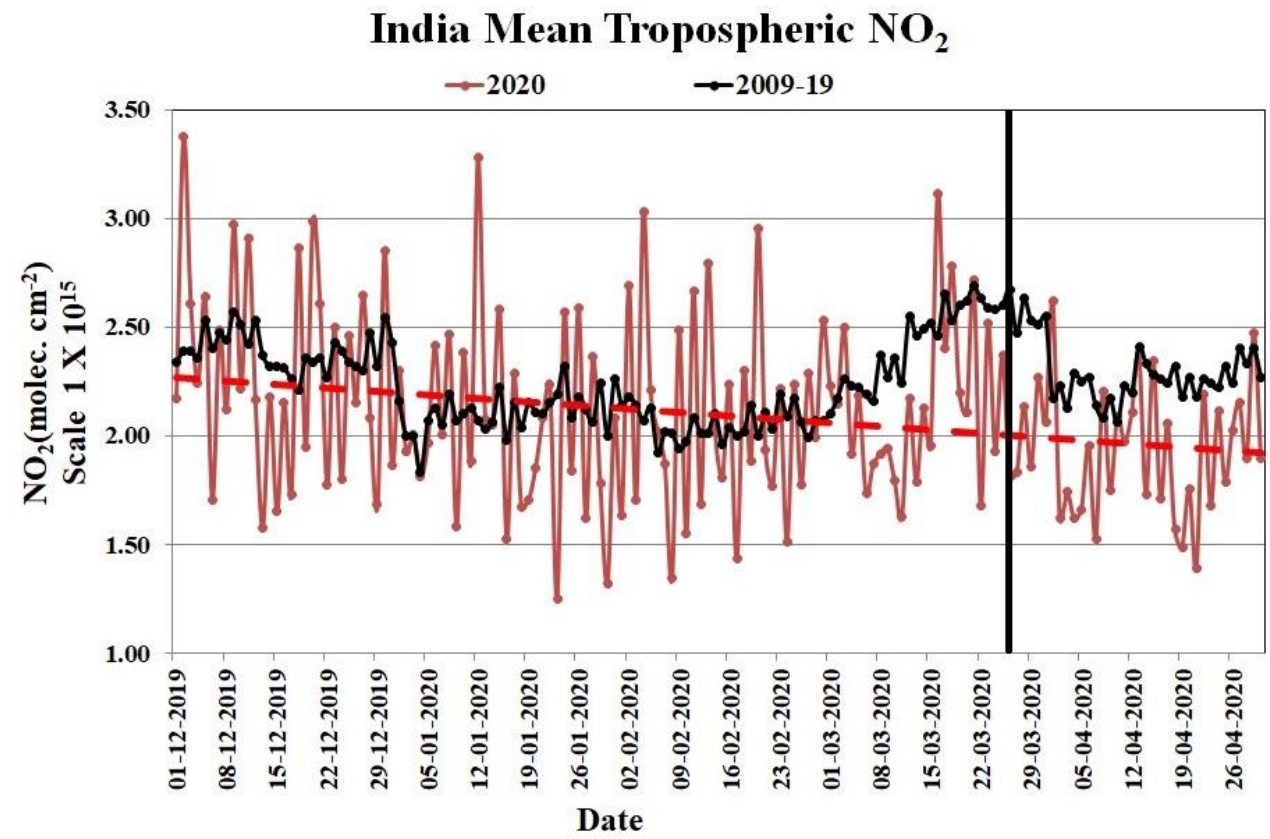

Fig. 5. Time series of area averaged values (December-April) of $\mathrm{NO}_{2}$ column density for 2009-19 (black) and 2020 (Red) for India. The black line shows the date when lockdown is started i.e., $25^{\text {th }}$ March. Red dash line shows trend line during Dec-April, 2020.

2020), atmospheric processes or due to city-specific changes in energy that are not well captured. Elevated $\mathrm{NO}_{2}$ concentrations are mostly found over Northern part of India including Punjab, Haryana, and western Uttar Pradesh regions as a direct consequence of the crop residue burning emissions. The time series of area averaged $\mathrm{NO}_{2}$ columnar density for 11 years mean of December to April 2009-2019 and 2020 over India shown in Fig. 5. It is evident that there is comparatively less decrease in $\mathrm{NO}_{2}$ emissions over India. This is because the lockdown in India was imposed on much later date i.e., $25^{\text {th }}$ March 2020. Therefore, improvement in the air quality emerged as a key benefit during this lockdown. During February month, the COVID-19 cases were very few in parts of India. Therefore, any effects on air quality due to this action would appear during the last week of March and the month of April. The monthly average $\mathrm{NO}_{2}$ columnar burden of $2.29 \pm 0.47 \times 10^{15}$ molec. $\mathrm{cm}^{-2}$ has been observed during December, 2019 which reduced to $2.05 \pm 0.42 \times 10^{15}$ molec. $\mathrm{cm}^{-2}$ during January, 2020. However, a slight increase of $2.09 \pm 0.46 \times$ $10^{15}$ molec. $\mathrm{cm}^{-2}$ and $2.12 \pm 0.34 \times 10^{15}$ molec. $\mathrm{cm}^{-2}$ has been observed during February, and March, 2020, respectively. The maximum drop in tropospheric $\mathrm{NO}_{2}$ column density has been found in April 2020 i.e., $1.92 \pm 0.31 \times 10^{15}$ molec. $\mathrm{cm}^{-2}$ after the lockdown started in India. Jain and Sharma (2020) also studied the ground observations of $\mathrm{NO}_{2}$ during the March and April months for five cities of India and found maximum reduction at Kolkata.

The mean tropospheric $\mathrm{NO}_{2}$ column of $2.32 \pm 0.15 \times 10^{15}$ molec. $\mathrm{cm}^{-2}$ and $1.95 \pm 0.30 \times 10^{15}$ molec. $\mathrm{cm}^{-2}$ are observed for 2009-19 and 2020 respectively during the lockdown ( $25^{\text {th }}$ March- 
$30^{\text {th }}$ April) period. Overall, a marked reduction of around $16 \%$ in tropospheric columnar burden of $\mathrm{NO}_{2(2020)}$ with that of $\mathrm{NO}_{2(2009-19)}$ is observed over India. This percentage changes lies in good agreement with the research done by Metya et al. (2020) and Pathakoti et al. (2020). There is not much reduction in $\mathrm{NO}_{2}$ because essential services during the lockdown has not stopped. This could be due to fact that over India, $\mathrm{NO}_{2}$ emissions from domestic cooking, and open burning of litter and biofuels might not have changed much during the restriction.

It is evident from Fig. 3 that high values of $\mathrm{NO}_{2}$ are found over most of the hotspots observed in the northern areas, in India. Therefore, we looked at the $\mathrm{NO}_{2}$ column burden over the IndoGangetic Plains (IGP) at the peak of confinement measures, which is densely populated and is prominent hot spot of emissions of major pollutants over India. This region is located at the foothills of Himalayas. It is mainly a wind convergence zone so other pollutants are transported into this region. The important pollution sources over IGP region are crop burning, fossil fuels and industrial emissions. So, the $\mathrm{NO}_{2}$ concentration remains higher over IGP than normal mean for all over India.

During the lockdown period, the mean tropospheric $\mathrm{NO}_{2}$ was $2.42 \pm 0.67 \times 10^{15}$ molec. $\mathrm{cm}^{-2}$ and $2.94 \pm 0.22 \times 10^{15}$ molec. $\mathrm{cm}^{-2}$ for 2020 and 2009-19, respectively. The tropospheric $\mathrm{NO}_{2}$ over IGP region is found higher by around $25 \%$ than whole India's mean during lockdown period connected to large scale crop residue events. During this period the escalating urban population, coupled with more demand in some sectors such as electricity generation, has resulted in elevated levels of $\mathrm{NO}_{2}$ emissions. The nation-wide lockdown was initiated in four phases over India i.e., Phase 1: 25 March 2020-14 April 2020 (21 days), Phase 2: 15 April 2020-3 May 2020 (19 days), Phase 3: 4 May 2020-7 May 2020 (14 days), Phase 4: 18 May 2020-31 May 2020 (14 days). A detailed analysis for the exact lockdown period over India from 25 ${ }^{\text {th }}$ March-31 May 2020 for all these phases has been shown in Annexure-1 for $\mathrm{NO}_{2}, \mathrm{SO}_{2}$ and $\mathrm{AOD}$.

\subsection{Variation in $\mathrm{SO}_{2}$ Concentration over China}

The study is further extended by adding another criterion pollutant i.e., $\mathrm{SO}_{2}$, which enters the atmosphere by combustion or burning of fossil fuels like coal oil and diesel or other substances that contains sulphur. These sources can be vehicles, power plants, metal manufacturing industries etc. This section utilises the $\mathrm{OMI} \mathrm{SO}_{2}$ data, which has been validated by Li et al. (2013) which shows a good agreement between the tropospheric $\mathrm{OMI}_{-} \mathrm{SO}_{2}$ column and ground-based measurements.

Fig. 6(a) shows the time series of averaged $\mathrm{SO}_{2}$ columnar data for December to April in Dobson unit (DU) for 2020 and 2009-19 over China. The mean (December-April) SO 2 (2020) column burden (0.0154 DU) shows an increase with that of $\mathrm{SO}_{2}$ (2019) columnar burden (0.0091 DU). Though, there is reduction of $53 \%$ in $\mathrm{SO}_{2}$ columnar density during (December-April) when $\mathrm{SO}_{2(2020)}$ was compared

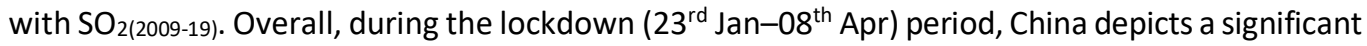
decrease in the $\mathrm{SO}_{2(2020)}$ columnar burden of $62 \%$ in comparison to $\mathrm{SO}_{2(2009-19)}$ columnar burden. The maxima during the lockdown period was 0.059 DU and 0.126 DU for 2020 and 2009-19.

The $\mathrm{SO}_{2}$ column burden are analysed by classification as described earlier for China. Table 2 shows the part-wise distribution of $\mathrm{SO}_{2}$ columnar burden. Most notable reductions are seen over NE (62\%) and SE (72\%) part of China where there is prominent decrease from January to April. However, the values extracted from $\mathrm{SO}_{2}$ satellite retrievals also contains negative columnar density. The negative values are discarded while calculating mean. This is due to the fact that sometimes the $\mathrm{SO}_{2}$ data might not give real values or real signals. This dissimilarity in pattern between $\mathrm{NO}_{2}$ and $\mathrm{SO}_{2}$ proves that satellite cannot detect low level $\mathrm{SO}_{2}$ signals which are emitted generally from vehicular emissions, fossil fuels etc. The noise in $\mathrm{NO}_{2}$ is however very small especially over more polluted areas like NE and SE provinces of China so therefore $\mathrm{NO}_{2}$ data is more reliable.

The $\mathrm{SO}_{2}$ columnar burden can reach as high as $1 \mathrm{DU}$ for major power plants, while the $\mathrm{SO}_{2}$ values of 0-0.2 (Krotkov et al., 2016) over South Asia are generally observed. In addition, for the Eastern India an average of around 0.14 DU has been reported earlier (Wang and Wang, 2020).

\subsection{Variation in $\mathrm{SO}_{2}$ Concentration over India}

As per NASA OMI satellite, India holds $15 \%$ of all $\mathrm{SO}_{2}$ hotspots of the world. Anthropogenic sources of this $\mathrm{SO}_{2}$ are fossil fuels in power plants and industrial activities (https://www.aa.com. tr/en/energy/coal/india-causing-concern-over-high-so2-emission-pollution/26335\#, last accessed 
(a)

China Mean Tropospheric $\mathrm{SO}_{2}$

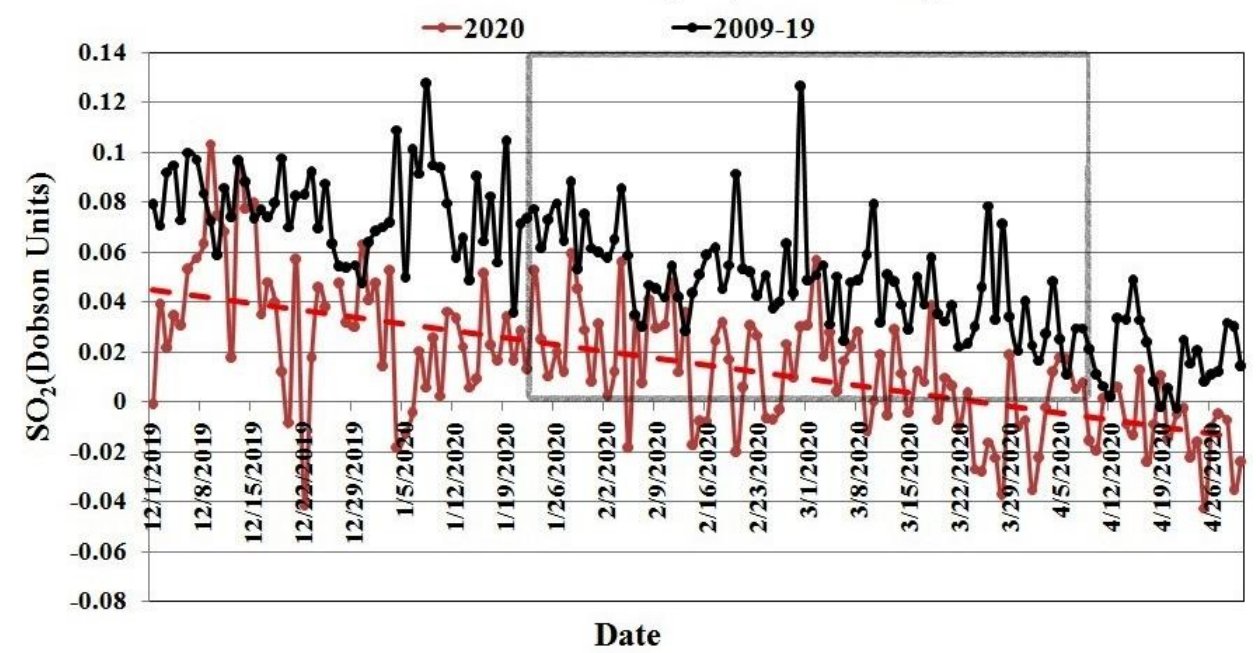

(b)

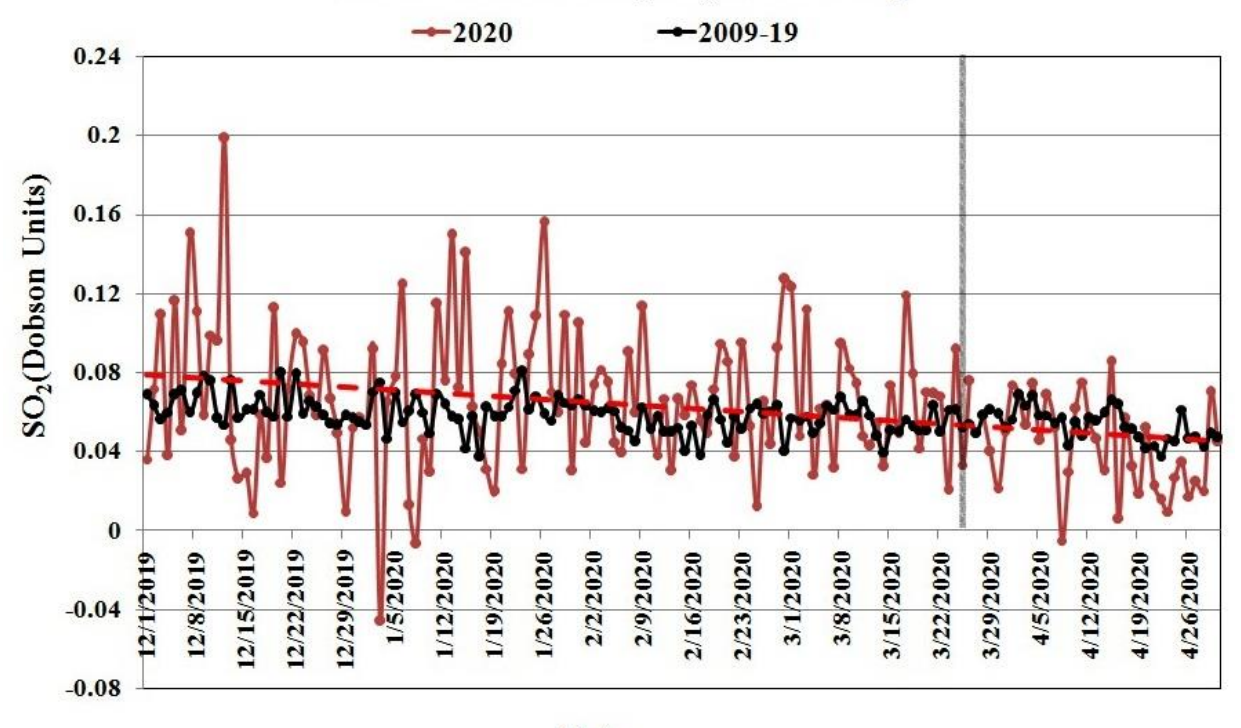

Date

Fig. 6. Time series of area averaged values of $\mathrm{SO}_{2}$ columnar burden (December-April) for 200919 (black) and 2019-20 (blue) for (a China and b) India.

Table 2. Monthly mean tropospheric $\mathrm{SO}_{2}$ columnar burden over $\mathrm{NE}, \mathrm{NW}, \mathrm{SW}, \mathrm{SE}$ part of China.

\begin{tabular}{lllllllll}
\hline Month & 2009-19_SW & 2020_SW & 2009-19_NW & 2020_NW & 2009-19_SE & 2020_SE & 2009-19_NE & 2020_NE \\
\hline January & 0.028 & 0.052 & 0.023 & 0.022 & 0.261 & 0.051 & 0.187 & 0.068 \\
February & 0.026 & 0.022 & 0.017 & 0.025 & 0.199 & 0.044 & 0.166 & 0.049 \\
March & 0.020 & 0.026 & 0.019 & 0.024 & 0.149 & 0.036 & 0.125 & 0.049 \\
April & 0.017 & 0.024 & 0.013 & 0.017 & 0.112 & 0.048 & 0.091 & 0.035 \\
\hline
\end{tabular}

Maximum reduction in $\mathrm{SO}_{2}$ columnar burden is seen in SE (72\%) and NE (62\%) China. Maximum Change is seen during February month for all four parts of China categorized. SE $(-78 \%)$ and NE $(-71 \%)$ China suffers maximum change during February.

05 ${ }^{\text {th }}$ May 2020). Fig. 6(b) shows the time series of averaged $\mathrm{SO}_{2}$ columnar data for December to April in Dobson unit (DU) for 2020 and 2009-19 over India. An increase of 8\% is observed in mean (December-April) $\mathrm{SO}_{2(2020)}$ to that of $\mathrm{SO}_{2(2009-19)}$ columnar burden over India. The maxima during the lockdown period is 0.2 DU and 0.1 DU for 2020 and 2009-19 respectively. However, the trend line of $\mathrm{SO}_{2}$ columnar burden over India shows prominent decrease ever since the lockdown 
started i.e., after 25 March 2020. The maximum reduction is observed during the April (20\%) over India. During the lockdown ( $25^{\text {th }}$ March-30 ${ }^{\text {th }}$ April) period over India, $\mathrm{SO}_{2}$ concentration shows a prominent decrease of around $17 \%$. This reduction is predominantly due to the temporary closure of large number of $\mathrm{SO}_{2}$ emission causing industries and other anthropogenic activities such as vehicular emissions that could be probable reasons of $\mathrm{SO}_{2}$ concentration over India.

The study is further extended by analysing the $\mathrm{SO}_{2}$ column burden over IGP region of India. Here also, the negative values are discarded while calculating mean. The IGP region of India experiences severe air pollution due to highly polluting thermal power plants. Because of denser population of IGP, pollution can cause some of the worst health impacts on humans. The range of $\mathrm{SO}_{2}$ exists between 0.01-1.2 DU from December-April with a maximum value of $0.13 \mathrm{DU}$ during the lockdown period. The $\mathrm{SO}_{2}$ values agrees well with the work done by Wang and Wang (2020). In general, the $\mathrm{SO}_{2(2020)}$ over IGP is $50 \%$ higher than India's $\mathrm{SO}_{2(2020)}$ for December-April. For lockdown period, the $\mathrm{SO}_{2}$ over IGP is $26 \%$ and $32 \%$ higher than India's $\mathrm{SO}_{2}$ mean and IGP SO $\mathrm{SO}_{2(2009 \text { - }}$ 19) mean, respectively.

\subsection{Variation in Al over China and India}

The TROPOMI Al retrieved value is positive for absorbing aerosols and negative for scattering aerosols. Values very close to zero indicate clouds, minimal or no aerosols or sun glint. High values of UVAI indicate increased loading of elevated absorbing aerosols often seen over desert or biomass burning regions. The main aerosol types that TROPOMI Al can detect are desert dust, biomass burning and volcanic ash plumes. The advantage of Al is that it can work even in cloudy conditions.

Fig. 7 shows the TROPOMI UVAI for 2020 (left), 2019 (right). During January 2020 (Fig. 7(a)), the values of $\mathrm{Al}$ are almost negative for India showing the dominance of scattering aerosols. During January 2019, slightly positive value (0-0.4) of Al are generally found in NW region of China showing the dominance of absorbing aerosols. For other regions of China, the values are in range of -1.2 to 0 . For India, the values lie in same range ( -1.2 to 0$)$. Bigger values of $\mathrm{Al}$ are found over the NW part of India during March and April months. These areas include Thar Desert and Rann of Kutch. The high values of Al above latitude $35^{\circ}$ north for the month after February shows the dominance of absorbing aerosols in the range of $0-0.8$ for China. However, the values over China for $\mathrm{Al}_{2020}$ are lower than $\mathrm{Al}_{2019}$. Prominent decrease is seen in NE and SE part of China. A clear picture is depicted from 7(c) of March where there are very few Al hotspots over NW and SE part of China for 2019 and 2020. NW part of China encompasses Qaidam Desert in Qaidam Basin, Badain Jaran desert in Ala Shan Plateau, Taklimakan Desert in Tarim Basin, Gurbantunggut Desert and other landscapes with higher dust aerosol emissions. Therefore, due to this fact the Al may be higher in pre-monsoon season. The high Al in SE China shows some biomass activity during March and April.

The monthly values for China and India show a decline in Al index. Monthly values show decline from 0.59 to 0.44 during January-April 2020 for China. This is likely due to decrease in absorbing aerosols over China resulting from reduced emissions. For India, there are not much significant changes in Al due to the fact that the countrywide lockdown was implemented later in March 2020. Higher Al or near to zero values are generally found during the pre-monsoon season (March-April-May) over Thar Desert and Rann of Kutch in NW India.

\subsection{Variation in AOD over China and India}

Fig. 8 shows the long-term monthly mean MODIS daily combined Terra and Aqua product for the duration 2020 (left), 2009-19 (middle) and percentage change (right, $A O D_{2020}-A_{O D} 2009-19$ ) during January, February, March and April. Generally, the AOD is higher in North East part of China due to burning of fossil fuels principally coal, heavy industries, construction sites etc. In addition, cities like Beijing, Shanghai that are among the most polluted cities of the world situated in this part.

Fig. 8(a) shows that during the January month the Indo-Gangetic Plains (IGP) and North-East parts of China are having very higher AOD, for 2009-19 as well as 2020. So, the difference between two images in that region is small. However, in total the AOD is lesser then 2009-19. The percentage change is calculated as

Percentage Change $A O D=100 \times\left(A_{20} 20-A O D_{2009-19}\right) / A O D_{2009-19}$ 
(a)

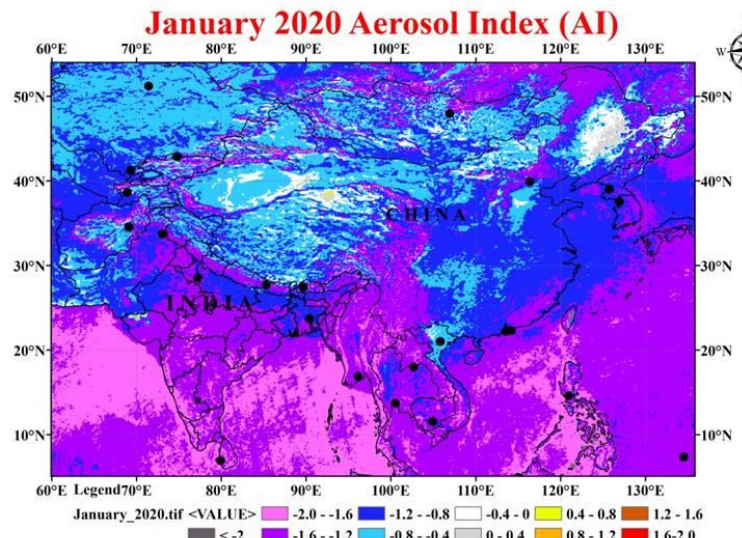

(b)

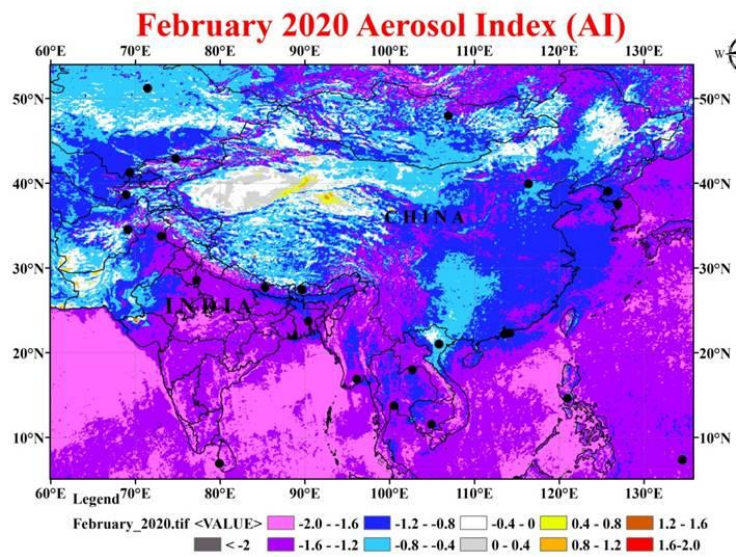

(c)

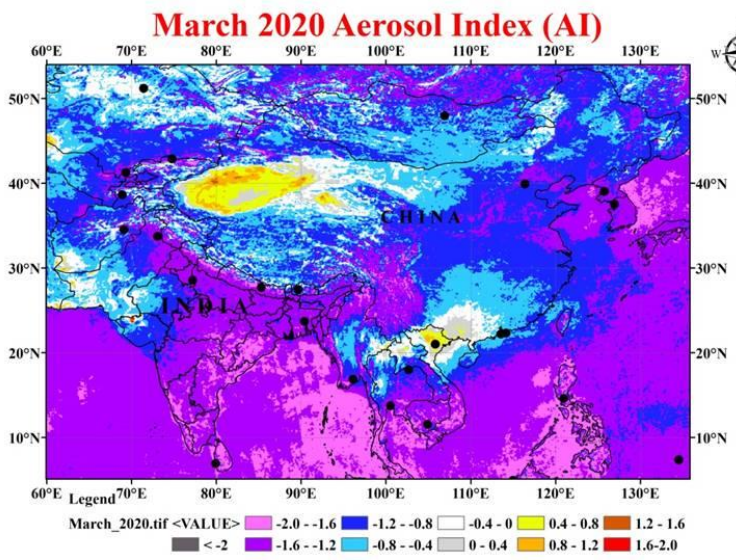

(d)

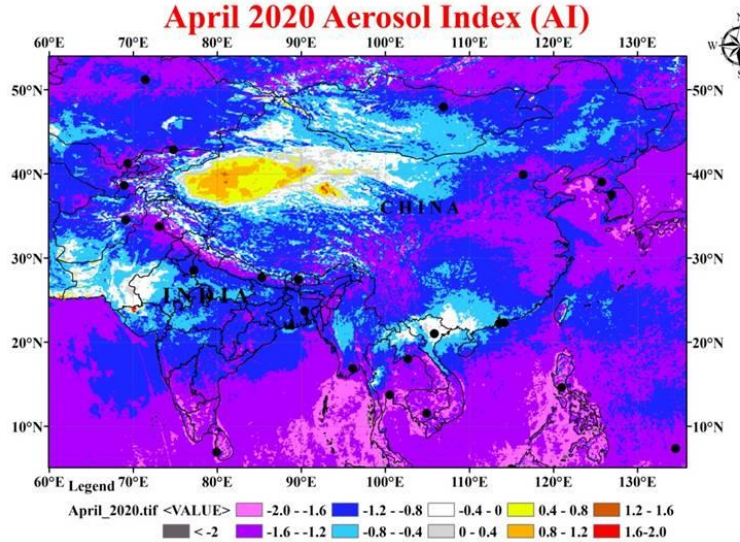

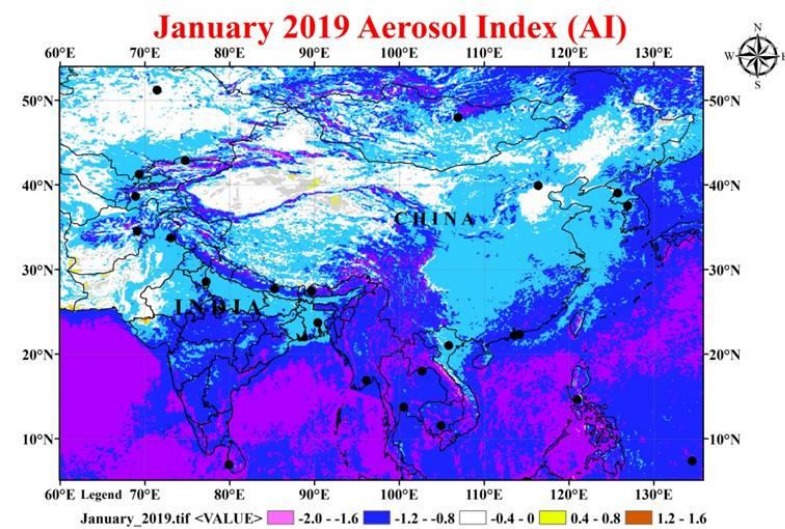

$<-2=-1.6-1.6-1.2-0.8 \square-0.4-0 \square-0.4-0.8 \square 1.2-1.6$
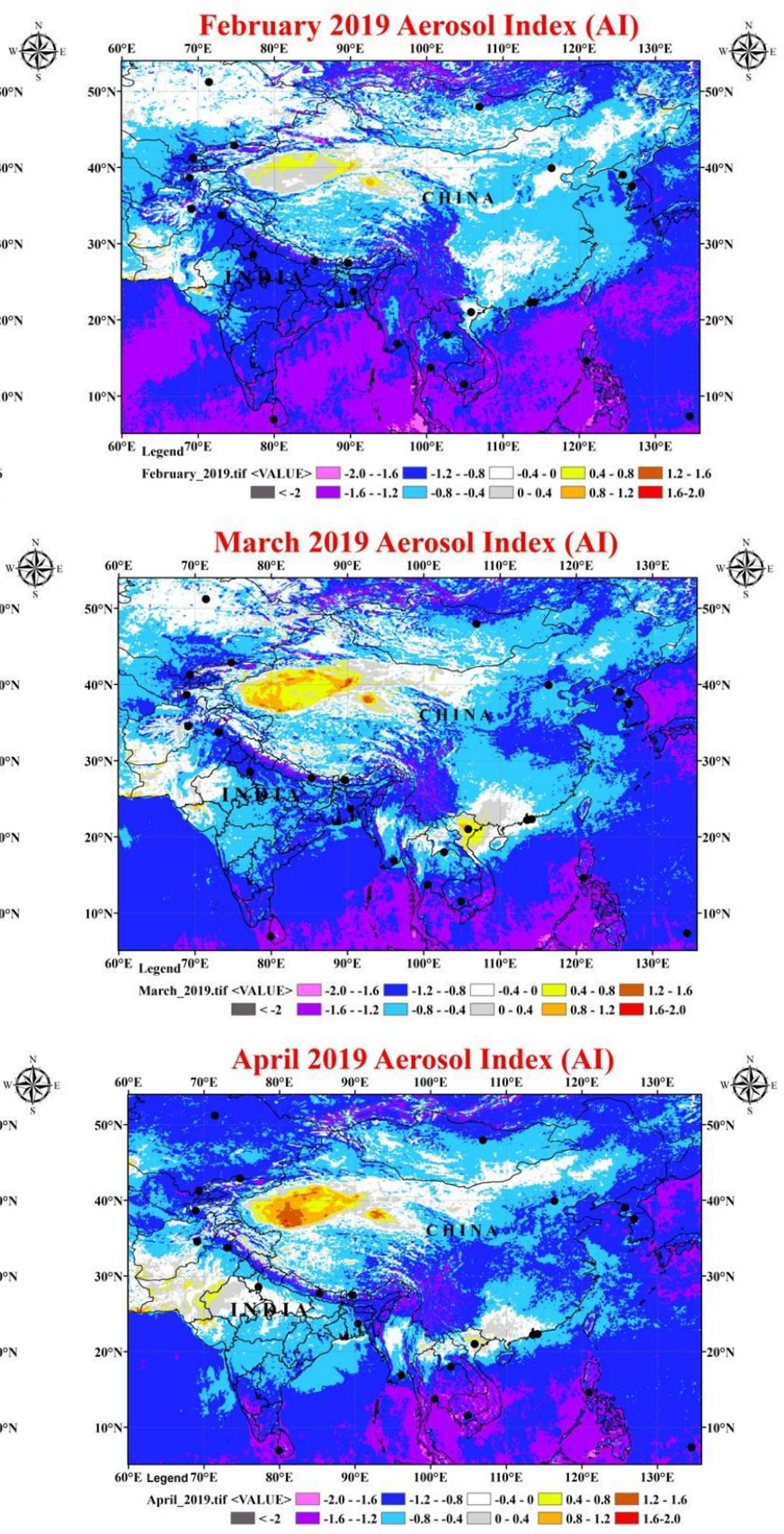

Fig. 7. TROPOMI UV Aerosol Index (Al) retrieved from Sentinel 5p for year 2020 (left), 2019 (right) over South-East Asia. Absorbing aerosols have positive Al value and scattering aerosol have negative Al. 
(a)

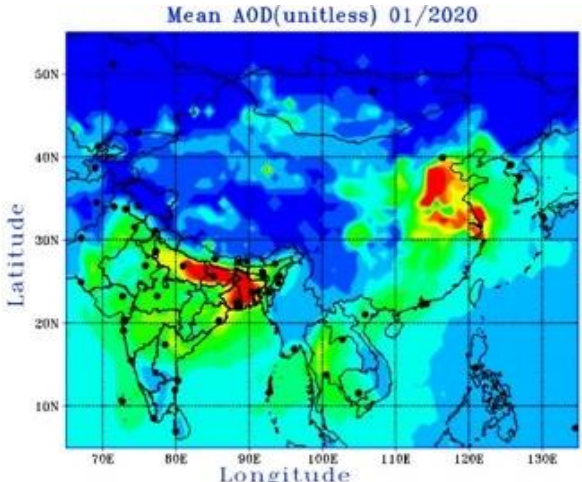

(b)

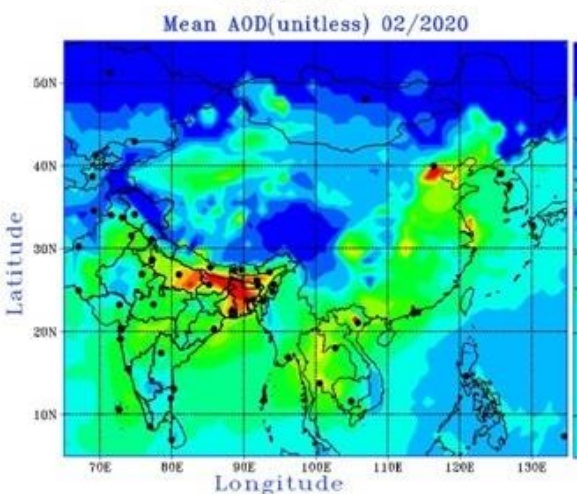

(c)

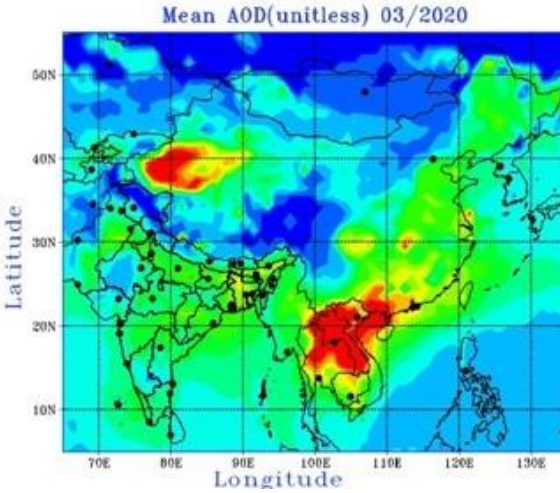

(d)

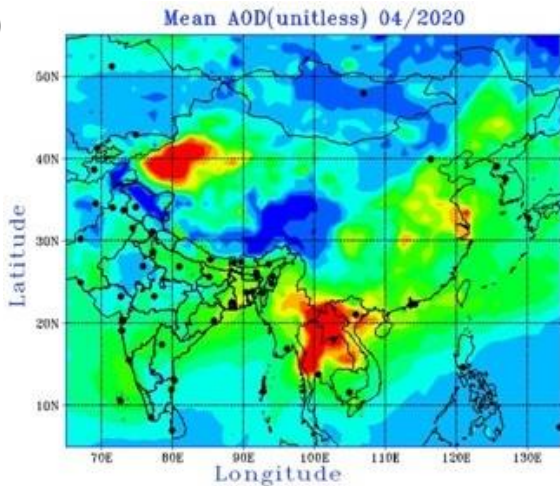

Mean AOD(unitless) 01/2009-19

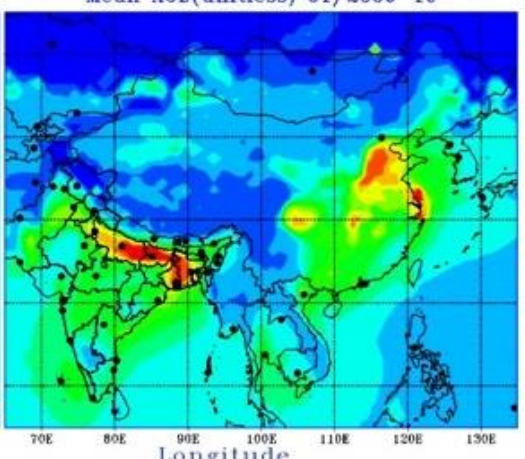

Mean AOD(unitless) 02/2009-19

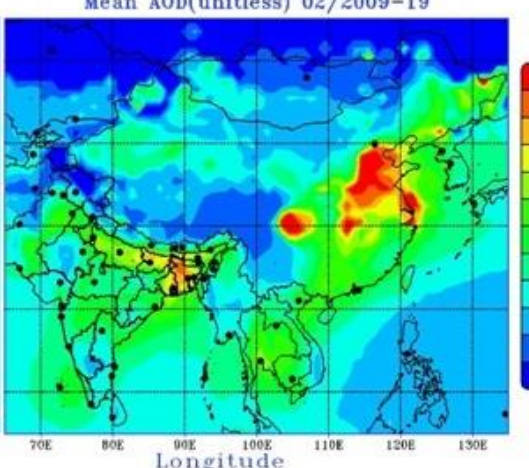

Mean AOD(unitless) 03/2009-19

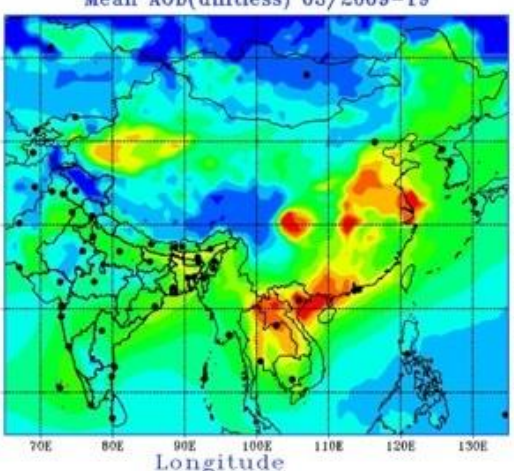

Mean AOD(unitless) 04/2009-19

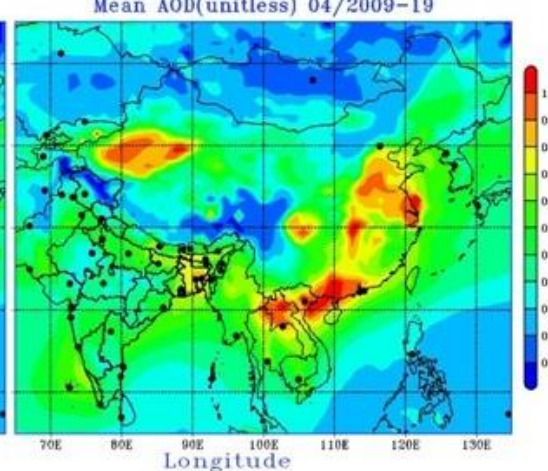

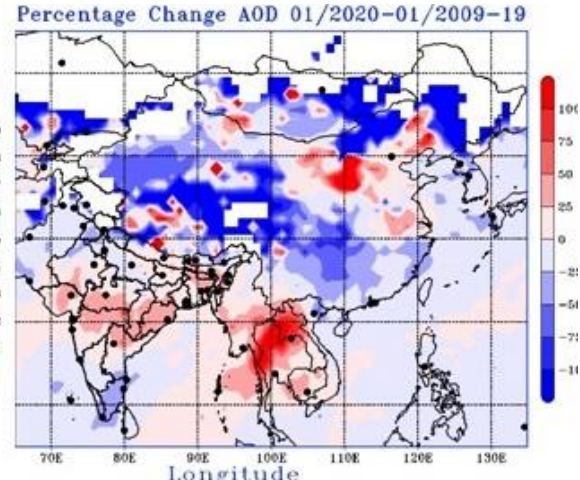
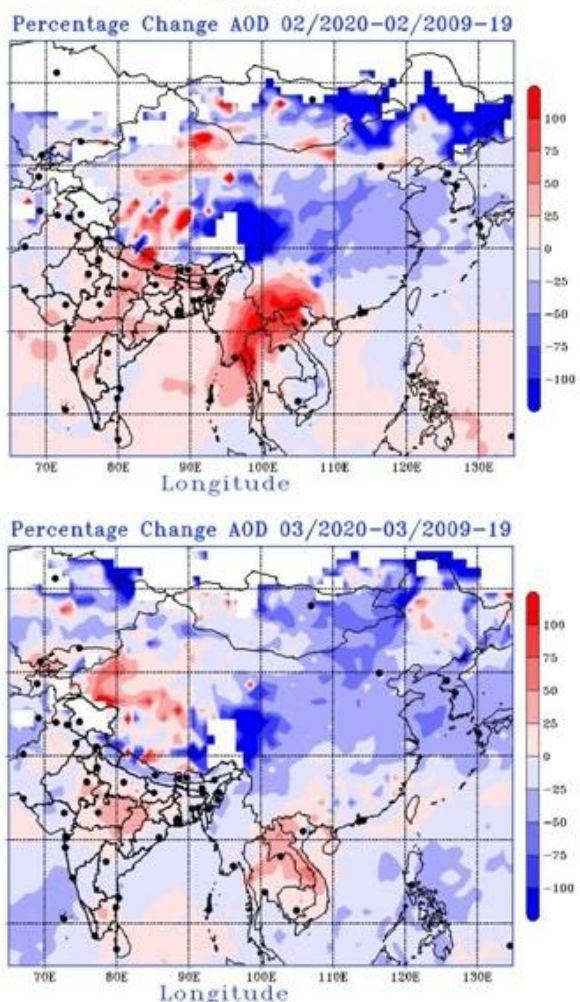

Percentage Change AOD 04/2020-04/2009-19

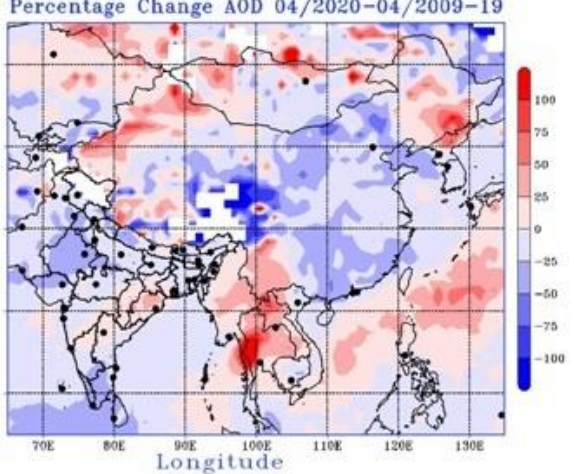

Fig. 8. Mean Aerosol Optical Depth 2020 (left), 2009-19 (middle) and percentage change (right) for (a) January, (b) February and (c) March and (d) April over China and India.

Fig. 8(b) shows that during February, $\mathrm{AOD}_{2020}$ is lower as compared to mean $\mathrm{AOD}_{2009-19}$ in most of the parts of China. Fig. 8 also shows there is almost $10 \%, 22 \%$ and $12 \%$ decrease noticed in North East China when $A O D_{2020}$ is compared with $A D_{2009-19}$ for February, March and April. However, percentage change is positive $(\approx+50 \%)$ for January. Other prominent changes are observed in South East China. Percentage change is negative for all months (January ( $\approx-15 \%)$, 
February $(\approx-27 \%)$, March $(\approx-16 \%)$ and April $(\approx-22 \%))$. SW China shows positive percentage change during all months. NW China shows negative change during January and February month while it shows positive change during March and April.

During March and April, the AOD is higher in NW China due to presence of dust aerosols (natural source) in pre-monsoon season. Due to COVID-19 situation and complete lockdown, there are less vehicular emissions as well as power plants or manufacturing industries. Therefore, the difference plot of February has higher negative values in most of the parts of China indicating year 2020 average AOD is much lower than 2009-19.

An overall drop by around $8 \%$ in AOD has been observed during the lockdown $\left(23^{\text {rd }}\right.$ January to

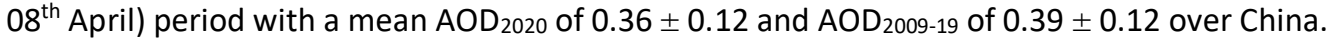

Over India (Fig. 8), the mean AOD during the lockdown (i.e., $25^{\text {th }}$ March-30 April) is $0.37 \pm 0.06$ and $0.42 \pm 0.02$ for 2020 and $2009-19$, respectively. This shows a reduction by around $12 \%$ in mean AOD. For India, the lockdown has started on $25^{\text {th }}$ March so changes that are more prominent during April. During the peak of confinement measures, the IGP region of India $A O D_{2020}$ is higher than $A O D_{2009-19}$.

The IGP region as seen from Fig. 8 for all the months has much higher AOD then normal mean of India. The AOD at $550 \mathrm{~nm}$ was $0.40 \pm 0.16$ and $0.50 \pm 0.05$ for 2020 and 2009-19 respectively. In general, the $A_{O D} D_{2009-19}$ over IGP is $19 \%$ higher than India's $A_{O D} 2009-19$ whereas the $A D_{2020}$ over IGP is $8 \%$ higher than India's $A_{20 D_{2020}}$

\subsection{Comparison with Ground Observations}

The MCD19A2 AOD from MODIS satellite was also compared with Aerosol Robotic NETwork (AERONET) CIMEL sun photometer observations of Level $2.0 \mathrm{AOD}$ at $550 \mathrm{~nm}$ at two stations one in China at Beijing $\left(39.97^{\circ} \mathrm{N}, 116.38^{\circ} \mathrm{E}\right)$ and one in India at Kanpur $\left(26.51^{\circ} \mathrm{N}, 80.23^{\circ} \mathrm{E}\right)$. These two sites are having long-term aerosol measurements. At Beijing the site is located at Institute of Atmospheric Physics, Chinese Academy of Sciences. At Kanpur the site is located at Department of Civil Engineering Indian Institute of Technology. Kanpur is located in central part of IGP region. It is one of the largest cities of India and is very densely populated. It is the center of many industrial activities. The scatter plot Fig. 9 below shows strong correlation of MODIS AOD with ground observations of AERONET AOD. The correlation is 0.93 and 0.82 for Beijing and Kanpur respectively. This also validates the MODIS retrievals. In addition, most of the points lie below the trend line, which shows underestimation by MODIS for both the sites.
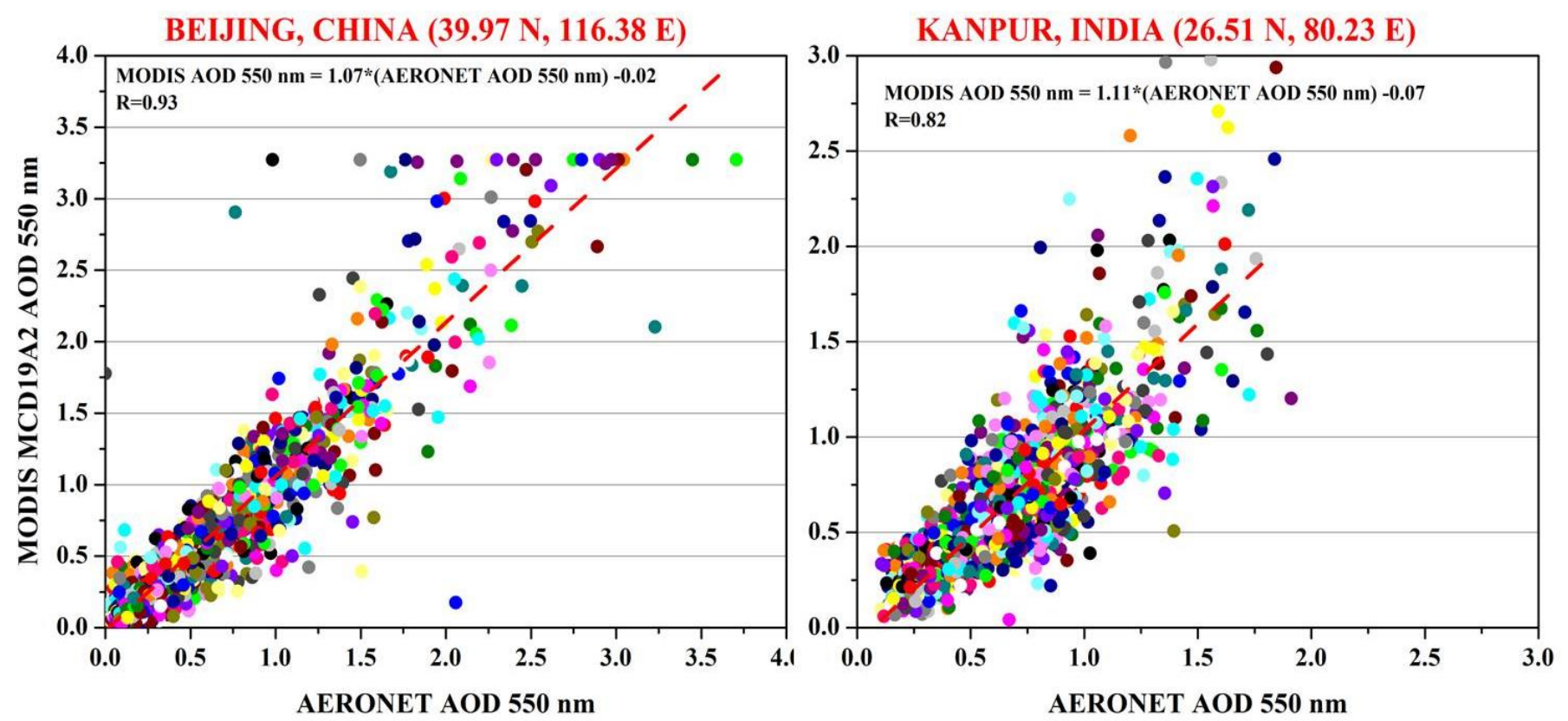

Fig. 9. Scatter graph between MODIS AOD and AERONET AOD 550nm Level 2.0 for Beijing and Kanpur. Correlation of 0.93 and 0.82 for Beijing and Kanpur, respectively. 
Time series for both these sites show the effect of lockdown on AOD at $550 \mathrm{~nm}$ (Fig. 10). After 23 January most of the times the mean AOD is below the 2009-19 average except on some occasions like on $13^{\text {th }}$ February $(A O D=3.14)$ and $06^{\text {th }}$ March $2020(A O D=1.98)$ for Beijing. Similarly, for Kanpur also the mean MODIS AOD is below the 2009-19 average except for some occasions like $22^{\text {nd }}$ February $(A O D=1.65)$ and $04^{\text {th }}$ March 2020 (1.02). However, after lockdown implementation in India all the values are below the 2009-19 MODIS AOD mean. The situation is very similar when AERONET observations of the two were compared (Fig. 11). The Fig. 11 shows the effect of lockdown in both India and China. Most of the cases are below the 2009-19 AOD level 2.0 average.
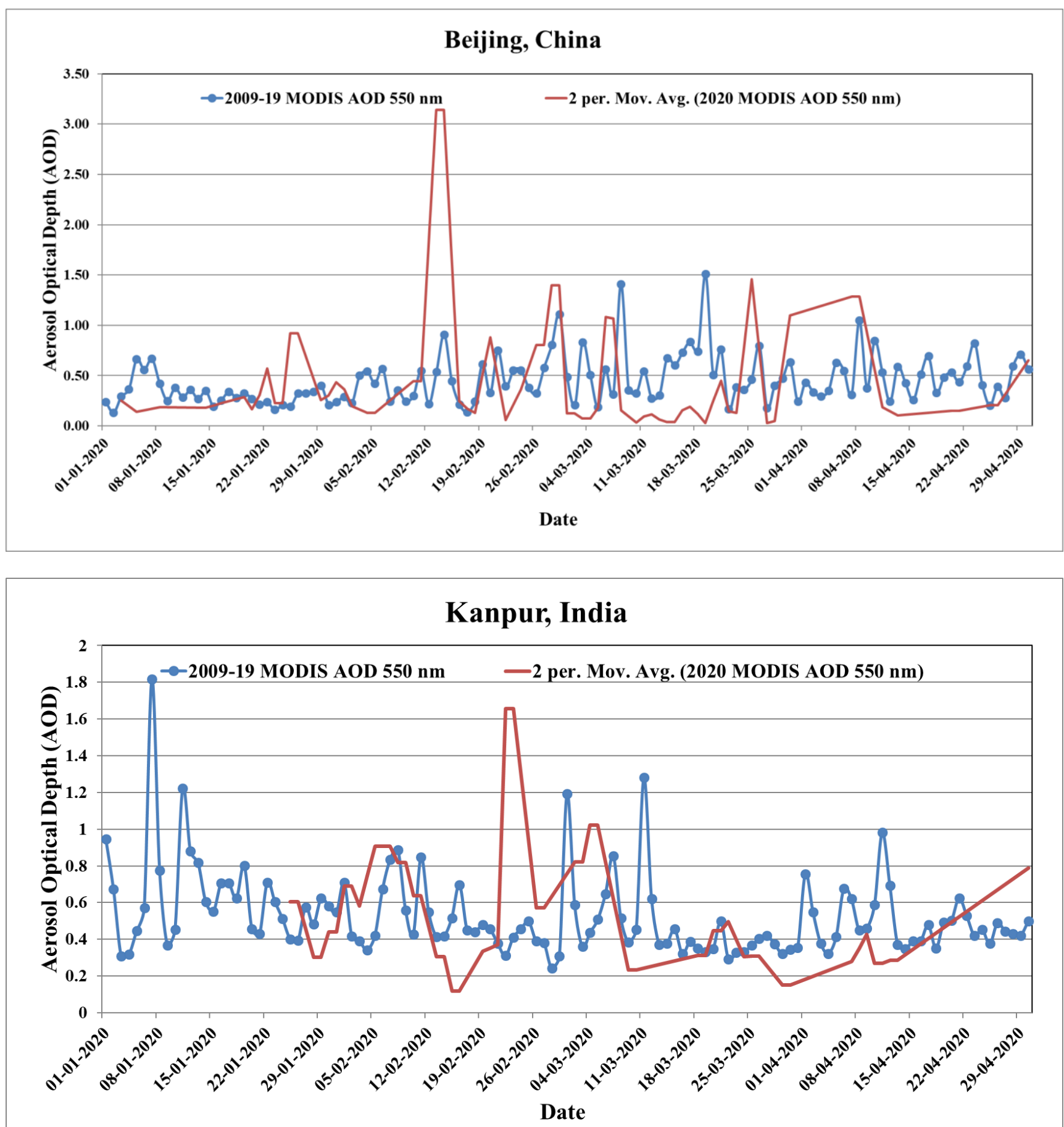

Fig. 10. Time series of mean MODIS AOD $550 \mathrm{~nm}$ between 2009-19 and 2020 for January to April for Beijing and Kanpur. 

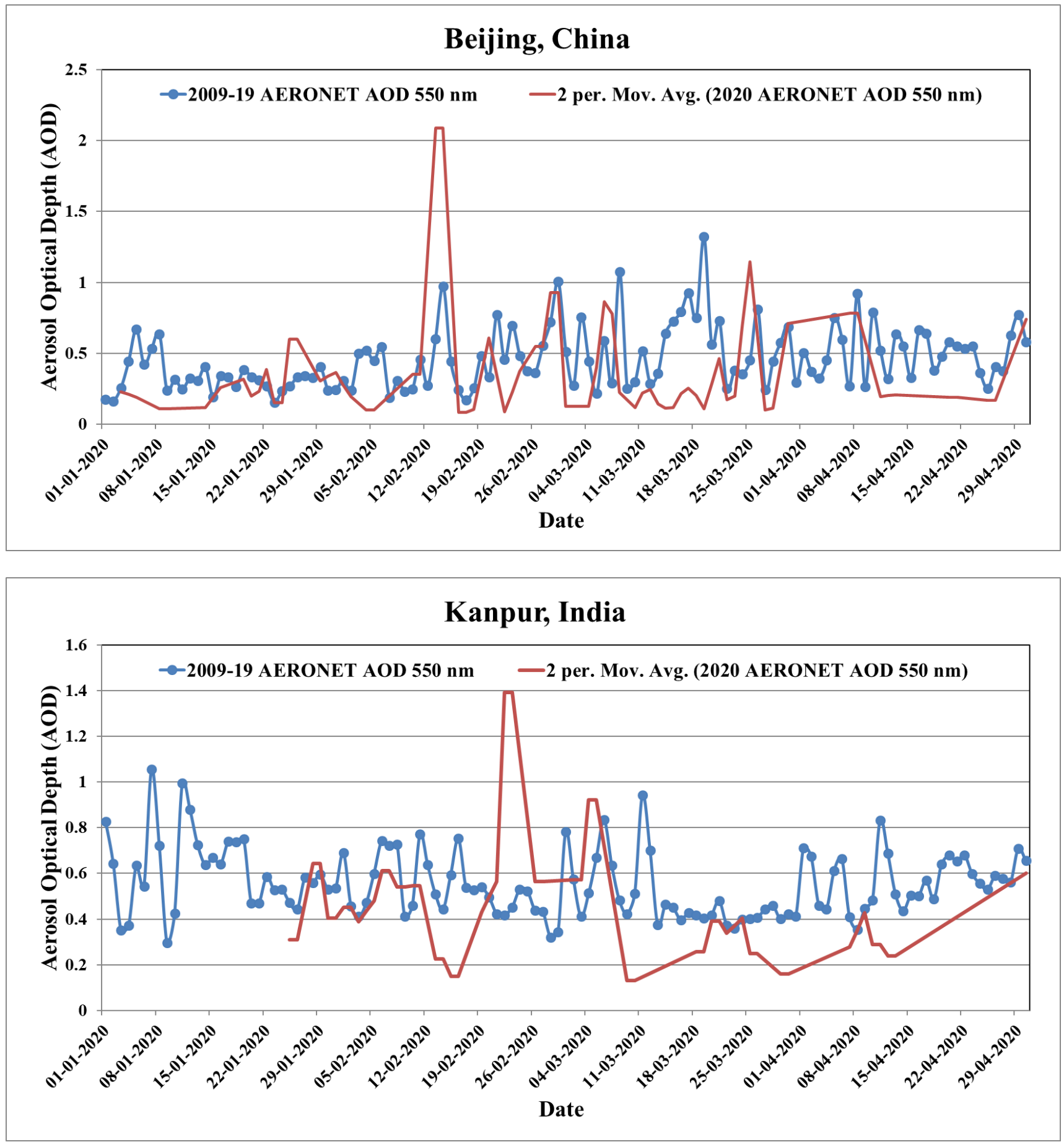

Fig. 11. Time series of mean AERONET AOD $550 \mathrm{~nm}$ between 2009-19 and 2020 for January to April for Beijing and Kanpur.

\subsection{Statistical Significance Using Paired T-test}

The significant impact of COVID-19 induced lockdown on air quality is explored using twotailed t-test. An assumption in form of two hypothesis are considered in t-test analysis to find whether mean concentration for all $\mathrm{AQ}$ indicators i.e., $\mathrm{NO}_{2}, \mathrm{SO}_{2}$ and $\mathrm{AOD}$ during 2020 and 200919 over China and India are significantly different from each other or not. A large t-test value indicates dissimilarity while a smaller value indicate similarity. The formulation of hypothesis is shown below.

(i) Null Hypothesis: It assumes that there is no significant difference between mean concentration of 2020 i.e., $\beta_{(2020)}$ and $2009-19$ ( $\left.\beta_{(2009-19)}\right)$. 
i.e., $\beta_{(2020)}-\beta_{(2009-19)} \cong 0$

(ii) Alternative Hypothesis: This assumes that there is significant difference between mean concentration of 2020 and 2009-19.

i.e., $\beta_{(2020)}-\beta_{(2009-19)}<0$

In (2) and (3), $\beta$ is mean concentration of $\mathrm{NO}_{2}, \mathrm{SO}_{2}$ and $\mathrm{AOD}$.

The t-test analysis of $\mathrm{NO}_{2}, \mathrm{SO}_{2}$ and $\mathrm{AOD}$ for China and India during lockdown period are shown in Table 3. A significant difference in mean concentration of $\mathrm{NO}_{2}(\mathrm{t}=-12.099, \mathrm{p}$-value $<0.001)$ between 2020 and 2009-19 over China is found (Table 3) during lockdown period. The t-test value and $p$-values is taken up to three significant digits. Larger $t$-value suggests dissimilarity due to less social, industrial activities in 2020 due to pandemic. There is significant difference in mean concentration of $\mathrm{NO}_{2}(\mathrm{t}=-7.407$, $\mathrm{p}$-value $<0.001$ ) between 2020 and 2009-19 over India.

The similar behaviour is observed for $\mathrm{SO}_{2}$ and $\mathrm{AOD}$ for China and India with $\mathrm{p}$-values $<0.05$. The small $p$-values $(t=-13.937$, $p$-value $<0.001)$ and $(t=-2.808$, $p$-value $<0.008)$ signifies the effect of COVID-19 lockdown and reduced $\mathrm{SO}_{2}$ concentration for China and India, respectively. Similarly, for AOD, statistically significant low $p$-values ( $t=-2.584$, $p$-value $<0.012$ ) are found over China and India ( $t=-5.419, p$-value $<0.001)$ at $95 \%$ confidence level during lockdown period. Therefore, the alternate hypothesis of statistically significant difference holds true. The larger t-test values of $\mathrm{NO}_{2}, \mathrm{SO}_{2}$ and $\mathrm{AOD}$ from statistical analysis suggests an improvement in air quality over both China and India during lockdown period.

\section{CONCLUSIONS}

A dramatic reduction in the column abundance of $\mathrm{NO}_{2}, \mathrm{SO}_{2}, \mathrm{Al}$ and $\mathrm{AOD}$ are evaluated over South-East Asia, a major region affected by the COVID-19 pandemic and resultant measures, including reduced activities and forced lockdown. The diminishing levels of pollution indicators in both TROPOMI and MODIS datasets are partially attributed to the measures taken to minimise the spread of SARS-CoV-2 virus. Since, $\mathrm{NO}_{2}$ is a primary pollutant and is much more strongly associated with traffic; the effect of country specific lockdown has more prominently seen in $\mathrm{NO}_{2}$ columnar concentration.

For China, OMI data show a significant drop of 37\% in tropospheric columnar burden of $\mathrm{NO}_{2(2020)}$ with that of $\mathrm{NO}_{2(2009-19)}$ during the lockdown period. The effect is found to be more prominent in the North East and South East region of China, where there is $42 \%$ and $32 \%$ decrease in $\mathrm{NO}_{2}$ columnar burden during the lockdown period. A significant percentage decrease of $62 \%$ in the columnar burden of $\mathrm{SO}_{2(2020)}$ with that of $\mathrm{SO}_{2(2009-19)}$ has also been found during lockdown period over China. Higher values of Al are shown by TROPOMI in NW China which is region having Badain Jaran, Taklimakan, Gurbantunggut deserts due to presence of absorbing aerosols (Dust). AOD exhibit higher values during pre-monsoon season (March-April) in NW China due to desert aerosols while higher $\mathrm{NO}_{2}$ emissions in $\mathrm{NE}$ and SE China. However, only $8 \%$ decrease is observed in the mean $\operatorname{AOD}_{(2020)}$ with that of $\operatorname{AOD}_{(2009-19)}$ during the lockdown period. The prominent decrease is

Table 3. Significance performance t-test of $\mathrm{NO}_{2}, \mathrm{SO}_{2}$ and $\mathrm{AOD}$ concentration over China and India.

\begin{tabular}{|c|c|c|c|c|c|c|c|}
\hline \multirow{2}{*}{ Region } & \multirow{2}{*}{ Pollutant } & \multirow{2}{*}{ Mean } & \multirow{2}{*}{ Std. Deviation } & \multicolumn{2}{|c|}{ 95\% Confidence Interval of the Difference } & \multirow{2}{*}{$\mathrm{t}$} & \multirow{2}{*}{ Sig. (2-tailed) } \\
\hline & & & & Lower & Upper & & \\
\hline \multirow[t]{3}{*}{ China } & $\mathrm{NO}_{2}$ & -0.953 & 0.691 & -1.110 & -0.797 & -12.099 & $<0.001$ \\
\hline & $\mathrm{SO}_{2}$ & -0.035 & 0.018 & -0.040 & -0.030 & -13.937 & $<0.001$ \\
\hline & AOD & -0.031 & 0.104 & -0.055 & -0.007 & -2.584 & 0.012 \\
\hline \multirow[t]{3}{*}{ India } & $\mathrm{NO}_{2}$ & -0.364 & 0.299 & -0.464 & -0.264 & -7.407 & $<0.001$ \\
\hline & $\mathrm{SO}_{2}$ & -0.009 & 0.019 & -0.016 & -0.002 & -2.808 & 0.008 \\
\hline & AOD & -0.051 & 0.057 & -0.070 & -0.032 & -5.419 & $<0.001$ \\
\hline
\end{tabular}

For China, the data is consisting of lockdown period from $23^{\text {rd }}$ January-0 ${ }^{\text {th }}$ April 2020 while a lockdown period from $25^{\text {th }}$ March-30 $0^{\text {th }}$ April 2020 for India are considered in t-test analysis. 
AOD is seen over SE China $(\approx 20 \%)$ during the lockdown period. The time series of Al shows a significant decline in absorbing aerosols over China. The time series plot of AOD retrievals also shows a decline over Beijing, China during lock down.

For India, the significant changes seen after March $25^{\text {th }} 2020$, when complete lockdown started. The average reduction was around $16 \%$ in mean tropospheric $\mathrm{NO}_{2}$ columnar density during the lockdown period for India. The IGP region also shows a reduction of around $18 \%$ in tropospheric $\mathrm{NO}_{2}$ columnar during the lockdown period. Though, for IGP region the tropospheric $\mathrm{NO}_{2}$ columnar was found $25 \%$ than whole India's mean during lockdown period.

The $\mathrm{SO}_{2}$ concentration shows a reduction of around $20 \%$ during the lockdown period for whole India. In contrast, the $\mathrm{SO}_{2}$ concentration over IGP region was found $26 \%$ higher than India's mean during lockdown period. For AOD, the maximum changes are seen over IGP region with reduction of around $20 \%$ against $12 \%$ for overall India. The aerosol index over IGP region shows a reduction of around $75 \%$ in absorbing aerosols against $50 \%$ for whole India. The time series plot of AOD retrievals shows a decline over Kanpur during lockdown. The larger $t$ and lower $p$-value than the pre-specified alpha level (0.05) in t-test analysis further suggest that difference between mean concentrations of 2020 with that of 2009-19 is statistically significantly different indicating an improvement in air quality over both China and India during COVID-19 lockdown period.

These drops are linked with strict quarantine; drop in demand for coal and oil, shutdown of industrial sectors, international travel bans and reduced individual automobile emissions. The results presented in this paper have demonstrated the impact of slow down or complete lockdown of large-scale activities such as transportation, vehicular traffic, and industries on the air pollution burden over the COVID-19 affected region of North East China. The COVID-19 pandemic has provided an unprecedented opportunity to investigate such large-scale reduction in the emissions of trace gases and aerosols, which is important to further strengthen the environmental policies to tackle the air quality, human health, and climate change in this part of the world. The reduction in air pollution has clear health benefits as it can save lives of millions of people worldwide every year. As pollution increases, it can also worsen the COVID-19 death rates, as the persons with pre-existing health conditions like respiratory and cardiovascular decreases are more at the risk. In fact, for protecting human health currently and even after the COVID-19 crisis we should enforce strict regulations for air pollution control.

\section{ACKNOWLEDGEMENTS}

OMI and MODIS Level 3 datasets were obtained from the Giovanni interface (http://giovanni. gsfc.nasa.gov/giovanni/), derived from the NASA Goddard Earth Sciences Data Active Archive Center (GES DISC; http://disc.sci.gsfc.nasa.gov). We also acknowledge the OMI, MODIS and AERONET mission groups for producing the long-term, reliable datasets used in this research effort. The authors acknowledge ESA for the S5P/TROPOMI product Aerosol Index. The authors also wish to express sincere thanks for the financial support from Indian Space Research Organization under Respond program, Government of India (ISRO/RES/3/806/19-20).

\section{CONFLICT OF INTERESTS}

The authors declare that there is no conflict of interests regarding the publication of this paper.

\section{SUPPLEMENTARY MATERIAL}

Supplementary data associated with this article can be found in the online version at https://doi.org/10.4209/aaqr.2020.06.0295

\section{REFERENCES}

Andersen, K.G., Rambaut, A., Lipkin, W.I., Holmes, E.C., Garry, R.F. (2020). The proximal origin of SARS-CoV-2. Nat. Med. 26, 450-452. https://doi.org/10.1038/s41591-020-0820-9 
Bera, B., Bhattacharjee, S., Shit, P.K., Sengupta, N., Saha, S. (2020). Significant impacts of COVID19 lockdown on urban air pollution in Kolkata (India) and amelioration of environmental health. Environ. Dev. Sustainability https://doi.org/10.1007/s10668-020-00898-5

Boersma, K.F., Eskes, H.J., Dirksen, R.J., van der A, R.J., Veefkind, J.P., Stammes, P., Huijnen, V., Kleipool, Q.L., Sneep, M., Claas, J., Leitão, J., Richter, A., Zhou, Y., Brunner, D. (2011). An improved tropospheric $\mathrm{NO}_{2}$ column retrieval algorithm for the Ozone Monitoring Instrument. Atmos. Meas. Tech. 4, 1905-1928. https://doi.org/10.5194/amt-4-1905

Boersma, K.F., Jacob, D.J., Bucsela, E.J., Perring, A.E., Dirksen, R., van der A, R.J., Yantosca, R.M., Park, R.J., Wenig, M.O., Bertram, T.H., Cohen, R.C. (2008). Validation of OMI tropospheric $\mathrm{NO}_{2}$ observations during INTEX-B and application to constrain $\mathrm{NO}_{\mathrm{x}}$ emissions over the eastern United States and Mexico. Atmos. Environ. 42, 4480-4497. https://doi.org/10.1016/j.atmosen v.2008.02.004

Bucsela, E.J., Krotkov, N.A., Celarier, E.A., Lamsal, L.N., Swartz, W.H., Bhartia, P.K., Boersma, K.F., Veefkind, J.P., Gleason, J.F., Pickering, K.E. (2013). A new stratospheric and tropospheric $\mathrm{NO}_{2}$ retrieval algorithm for nadir-viewing satellite instruments: Applications to OMI. Atmos. Meas. Tech. 6, 2607-2626. https://doi.org/10.5194/amt-6-2607-2013

Carlos, W.G., Dela Cruz, C.S., Cao, B., Pasnick, S., Jamil, S. (2020). COVID-19 Disease due to SARSCoV-2 (Novel Coronavirus). Am. J. Respir. Crit. Care Med. 201, P7-P8. https://doi.org/10.1164/ rccm.2014P7

Centers for Disease Control and Prevention (CDC) (2020). Coronavirus disease 2019 (COVID-19) situation summary. 2020-01-30) [2020-02-01]. https://www.cdc.gov/coronavirus/2019ncov/summary.html

Chandrashekhar, V. (2020). 1.3 billion people. A 21-day lockdown. Can India curb the coronavirus? Science https://doi.org/10.1126/science.abc0030

Dalziel, B.D., Kissler, S., Gog, J.R., Viboud, C., Bjørnstad, O.N., Metcalf, C.J.E., Grenfell, B.T. (2018). Urbanization and humidity shape the intensity of influenza epidemics in US cities. Science 362 75-79. https://doi.org/10.1126/science.aat6030

Dobber, M., Dirksen, R., Voors, R., Mount, G.H., Levelt, P. (2005). Ground-based zenith sky abundances and in situ gas cross sections for ozone and nitrogen dioxide with the Earth Observing System Aura Ozone Monitoring Instrument. Appl. Opt. 44, 2846-2856. https://doi.org/10.1364/AO.44.002846

Dobber, M.R., Dirksen, R.J., Levelt, P.F., Oord, G.H.J. van den, Voors, R.H.M., Kleipool, Q., Jaross, G., Kowalewski, M., Hilsenrath, E., Leppelmeier, G.W., Johan de Vries, Dierssen, W., Rozemeijer, N.C. (2006). Ozone monitoring instrument calibration. IEEE Trans. Geosci. Remote Sens. 44, 1209-1238. https://doi.org/10.1109/TGRS.2006.869987

Dobber, M., Kleipool, Q., Dirksen, R., Levelt, P., Jaross, G., Taylor, S., Kelly, T., Flynn, L., Leppelmeier, G., Rozemeijer, N. (2008). Validation of Ozone Monitoring Instrument level 1b data products. J. Geophys. Res. 113, D15S06. https://doi.org/10.1029/2007JD008665

Filonchyk, M., Hurynovich, V., Yan, H., Gusev, A., Shpilevskaya, N. (2020). Impact assessment of COVID-19 on variations of $\mathrm{SO}_{2}, \mathrm{NO}_{2}, \mathrm{CO}$ and $\mathrm{AOD}$ over east China. Aerosol Air Qual. Res. 20, 1530-1540. https://doi.org/10.4209/aaqr.2020.05.0226

Gautam, S. (2020). The influence of COVID-19 on air quality in India: A boon or inutile. Bull. Environ. Contam. Toxicol. 104, 724-726. https://doi.org/10.1007/s00128-020-02877-y

Ghude, S.D., Fadnavis, S., Beig, G., Polade, S.D., Van Der A, R.J. (2008). Detection of surface emission hot spots, trends, and seasonal cycle from satellite-retrieved $\mathrm{NO}_{2}$ over India. J. Geophys. Res. 113, D20305. https://doi.org/10.1029/2007JD009615

Gorbalenya, A.E., Baker, S.C., Baric, R.S., de Groot, R.J., Drosten, C., Gulyaeva, A.A., Haagmans, B.L., Lauber, C., Leontovich, A.M., Neuman, B.W., Penzar, D., Perlman, S., Poon, L.L.M., Samborskiy, D.V., Sidorov, I.A., Sola, I., Ziebuhr, J., Coronaviridae Study Group of the International Committee on Taxonomy of Viruses (2020). The species Severe acute respiratory syndrome-related coronavirus: CLASSIFYING 2019-nCoV and naming it SARS-CoV-2. Nat. Microbiol. 5, 536-544. https://doi.org/10.1038/s41564-020-0695-z

Hemmes, J.H., Winkler, K., Kool, S.M. (1960). Virus survival as a seasonal factor in influenza and poliomyelitis. Nature 188,430-431. https://doi.org/10.1038/188430a0

Jain, S., Sharma, T. (2020). Social and travel lockdown impact considering coronavirus disease (COVID-19) on air quality in megacities of India: Present benefits, future challenges and way 
forward. Aerosol Air Qual. Res. 20, 1222-1236. https://doi.org/10.4209/aaqr.2020.04.0171

Jing, G. (2020). Diary of a life in locked-down Wuhan. https://www.bbc.com/news/worldasiachina-51276656 (accessed 1 April 2020).

Kang, N., Kumar, K.R., Yu, X., Yin, Y. (2016). Column-integrated aerosol optical properties and direct radiative forcing over the urban-industrial megacity Nanjing in the Yangtze River Delta, China. Environ. Sci. Pollut. Res. 23, 17532-17552. https://doi.org/10.1007/s11356-016-6953-1

Kendrick, C. M., Koonce, P., George, L.A. (2015). Diurnal and seasonal variations of NO, $\mathrm{NO}_{2}$ and $\mathrm{PM}_{2.5}$ mass as a function of traffic volumes alongside an urban arterial. Atmos. Environ. 122, 133-141. https://doi.org/10.1016/j.atmosenv.2015.09.019

Krotkov, N. A., Lamsal, L. N., Marchenko, S. V., Celarier, E. A., Bucsela E.J., Swartz W.H., Joiner J., and the OMI core team (2019). OMI/Aura Nitrogen Dioxide (NO2) Total and Tropospheric Column 1-orbit L2 Swath $13 \times 24$ km V003, Greenbelt, MD, USA, Goddard Earth Sciences Data and Information Services Center (GES DISC), https://doi.org/10.5067/Aura/OMI/DATA2017 (accessed 5 April 2020).

Krotkov, N.A., Li, C., Leonard, P. (2015). OMI/Aura sulfur dioxide ( $\left.\mathrm{SO}_{2}\right)$ Total Column $\mathrm{L} 31$ day Best Pixel in 0.25 degreex 0.25 degree V3, Greenbelt, MD, USA, Goddard Earth Sciences Data and Information Services Center (GES DISC).

Krotkov, N.A., McLinden, C.A., Li, C., Lamsal, L.N., Celarier, E.A., Marchenko, S.V., Swartz, W.H., Bucsela, E.J., Joiner, J., Duncan, B.N., Boersma, K.F., Veefkind, J.P., Levelt, P.F., Fioletov, V.E., Dickerson, R.R., He, H., Lu, Z., Streets, D.G. (2016). Aura OMI observations of regional $\mathrm{SO}_{2}$ and $\mathrm{NO}_{2}$ pollution changes from 2005 to 2015. Atmos. Chem. Phys. 16, 4605-4629. https://doi.org/10.5194/acp-16-4605-2016

Kurosu, T.P., Chance, K., Sioris, C.E. (2004). Preliminary results for $\mathrm{HCHO}$ and BrO from the EOSAura Ozone Monitoring Instrument, in: Passive Optical Remote Sensing of the Atmosphere and Clouds IV, Presented at the Passive Optical Remote Sensing of the Atmosphere and Clouds IV, International Society for Optics and Photonics, pp. 116-123. https://doi.org/10.1117/12.578606

Lai, C.C., Shih, T.P., Ko, W.C., Tang, H.J., Hsueh, P.R. (2020). Severe acute respiratory syndrome coronavirus 2 (SARS-CoV-2) and corona virus disease-2019 (COVID-19): The epidemic and the challenges. Int. J. Antimicrob. Agents 55, 105924. https://doi.org/10.1016/j.ijantimicag.2020. 105924

Lamsal, L.N., Krotkov, N.A., Celarier, E.A., Swartz, W.H., Pickering, K.E., Bucsela, E.J., Gleason, J.F., Martin, R.V., Philip, S., Irie, H., Cede, A., Herman, J., Weinheimer, A., Szykman, J.J., Knepp, T.N. (2014). Evaluation of OMI operational standard $\mathrm{NO}_{2}$ column retrievals using in situ and surfacebased $\mathrm{NO}_{2}$ observations. Atmos. Chem. Phys. 14, 11587-11609. https://doi.org/10.5194/acp14-11587-2014

Le, T., Wang, Y., Liu, L., Yang, J., Yung, Y.L., Li, G., Seinfeld, J.H. (2020). Unexpected air pollution with marked emission reductions during the COVID-19 outbreak in China. Science 369, 702706. https://doi.org/10.1126/science.abb7431

Levelt, P.F., Hilsenrath, E., Leppelmeier, G.W., van den Oord, G.H.J., Bhartia, P.K., Tamminen, J., de Haan, J.F., Veefkind, J.P. (2006). Science objectives of the ozone monitoring instrument. IEEE Trans. Geosci. Remote Sens. 44, 1199-1208. https://doi.org/10.1109/TGRS.2006.872336

Levelt, P.F., Joiner, J., Tamminen, J., Veefkind, J.P., Bhartia, P.K., Stein Zweers, D.C., Duncan, B.N., Streets, D.G., Eskes, H., van der A, R., McLinden, C., Fioletov, V., Carn, S., de Laat, J., DeLand, M., Marchenko, S., McPeters, R., Ziemke, J., Fu, D., Liu, X., ... Wargan, K. (2018). The Ozone Monitoring Instrument: overview of 14 years in space. Atmos. Chem. Phys. 18, 5699-5745. https://doi.org/10.5194/acp-18-5699-2018

Levy, R.C., Mattoo, S., Munchak, L.A., Remer, L.A., Sayer, A.M., Patadia, F., Hsu, N.C. (2013). The Collection 6 MODIS aerosol products over land and ocean. Atmos. Meas. Tech. 6, 2989-3034. https://doi.org/10.5194/amt-6-2989-2013

Li, C., Joiner, J., Krotkov, N.A., Bhartia, P.K. (2013). A fast and sensitive new satellite $\mathrm{SO}_{2}$ retrieval algorithm based on principal component analysis: Application to the ozone-monitoring instrument. Geophys. Res. Lett. 40, 6314-6318. https://doi.org/10.1002/2013GL058134

Li, Q., Guan, X., Wu, P., Wang, X., Zhou, L., Tong, Y., Ren, R., Leung, K.S., Lau, E.H., Wong, J.Y., Xing, X. (2020). Early transmission dynamics in Wuhan, China, of novel coronavirus-Infected pneumonia. N. Engl. J. Med. 382, 1199-1207. https://doi.org/10.1056/NEJMoa2001316

Mahato, S., Ghosh, K.G. (2020). Short-term exposure to ambient air quality of the most polluted 
Indian cities due to lockdown amid SARS-CoV-2. Environ. Res. 188, 109835. https://doi.org/10. 1016/j.envres.2020.109835

Marchenko, S.V., DeLand, M.T. (2014). Solar spectral irradiance changes during cycle 24. Astrophys. J. 789, 117. https://doi.org/10.1088/0004-637x/789/2/117

Metya, A., Dagupta, P., Halder, S., Chakraborty, S., Tiwari, Y.K. (2020). COVID-19 Lockdowns improve air quality in the south-east Asian regions, as seen by the remote sensing satellites. Aerosol Air Qual. Res. 20, 1772-1782. https://doi.org/10.4209/aaqr.2020.05.0240

Nakada, L.Y.K., Urban, R.C. (2020). COVID-19 pandemic: Impacts on the air quality during the partial lockdown in São Paulo state, Brazil. Sci. Total Environ. 730, 139087. https://doi.org/10.1 016/j.scitotenv.2020.139087

Pathakoti, M., Muppalla, A., Hazra, S., Dangeti, M., Shekhar, R., Jella, S., Mullapudi, S.S., Andugulapati, P., Vijayasundaram, U. (2020). An assessment of the impact of a nation-wide lockdown on air pollution - a remote sensing perspective over India. Atmos. Chem. Phys. Discuss. [preprint] https://doi.org/10.5194/acp-2020-621

Payra, S., Soni, M., Kumar, A., Prakash, D., Verma, S. (2015). Intercomparison of aerosol optical thickness derived from MODIS and in situ ground datasets over Jaipur, a semi-arid zone in India. Environ. Sci. Technol. 49, 9237-9246. https://doi.org/10.1021/acs.est.5b02225

Ranjan, A.K., Patra, A.K., Gorai, A.K. (2020). Effect of lockdown due to SARS COVID-19 on aerosol optical depth (AOD) over urban and mining regions in India. Sci. Total Environ. 745, 141024. https://doi.org/10.1016/j.scitotenv.2020.141024

Robson, B. (2020). Computers and viral diseases. Preliminary bioinformatics studies on the design of a synthetic vaccine and a preventative peptidomimetic antagonist against the SARS-CoV-2 (2019-nCoV, COVID-19) coronavirus. Comput. Biol. Med. 119, 103670. https://doi.org/10.1016/ j.compbiomed.2020.103670

Schenkeveld, V.E., Jaross, G., Marchenko, S., Haffner, D., Kleipool, Q.L., Rozemeijer, N.C., Veefkind, J.P., Levelt, P.F. (2017). In-flight performance of the Ozone Monitoring Instrument. Atmos. Meas. Tech. 10, 1957-1986. https://doi.org/10.5194/amt-10-1957-2017

Singh, R.P., Chauhan, A. (2020). Impact of lockdown on air quality in India during COVID-19 pandemic. Air Qual. Atmos. Health 13, 921-928. https://doi.org/10.1007/s11869-020-00863-1

Tobías, A., Carnerero, C., Reche, C., Massagué, J., Via, M., Minguillón, M.C., Alastuey, A., Querol, $X$. (2020). Changes in air quality during the lockdown in Barcelona (Spain) one month into the SARS-CoV-2 epidemic. Sci. Total Environ. 726, 138540. https://doi.org/10.1016/j.scitotenv.2020. 138540

Wang, J., Tang, K., Feng, K., Li, X., Lv, W., Chen, K., Wang, F. (2020a). High temperature and high humidity reduce the transmission of COVID-19. arXiv:2003.05003

Wang, P., Chen, K., Zhu, S., Wang, P., Zhang, H. (2020b). Severe air pollution events not avoided by reduced anthropogenic activities during COVID-19 outbreak. Resour. Conserv. Recycl. 158, 104814. https://doi.org/10.1016/j.resconrec.2020.104814

Wang, W., Xu, Y., Gao, R., Lu, R., Han, K., Wu, G., Tan, W. (2020c). Detection of SARS-CoV-2 in different types of clinical specimens. JAMA 323, 1843-1844. https://doi.org/10.1001/jama.20 20.3786

Wang, Y., Wang, J. (2020). Tropospheric $\mathrm{SO}_{2}$ and $\mathrm{NO}_{2}$ in 2012-2018: Contrasting views of two sensors (OMI and OMPS) from space. Atmos. Environ. 223, 117214. https://doi.org/10.1016/j. atmosenv.2019.117214

Watts, J., Kommenda, N. (2020). Coronavirus pandemic leading to huge drop in air pollution. The Guardian 23. https://www.theguardian.com/environment/2020/mar/23/coronavirus-pandemicleading-to-huge-drop-in-air-pollution (accessed August 19, 2020).

World Health Organization (WHO) (2020a). WHO Director-General's opening remarks at the media briefing on COVID-19 - 11 March 2020, viewed 25 March 2020. https://www.who.int/dg/ speeches/detail/who-director-general-s-opening-remarks-at-the-media-briefing-on-covid-19--11-march-2020

World Health Organization (WHO) (2020b). Novel Coronavirus (2019-nCoV) Situation Report - 1 World Health Organization. https://apps.who.int/iris/handle/10665/330760

World Health Organization (WHO) (2020c). Novel Coronavirus (2019-nCoV) Situation Report - 22. World Health Organization. https://apps.who.int/iris/handle/10665/330991

World Health Organization (WHO) (2020d). Coronavirus disease 2019 (COVID-19) Situation 
Report - 101. World Health Organization. https://apps.who.int/iris/handle/10665/332054

Wu, F., Zhao, S., Yu, B., Chen, Y.M., Wang, W., Song, Z.G., Hu, Y., Tao, Z.W., Tian, J.H., Pei, Y.Y., Yuan, M.L. (2020). A new coronavirus associated with human respiratory disease in China. Nature 579, 265-269. https://doi.org/10.1038/s41586-020-2008-3

Xu, K., Cui, K., Young, L.H., Hsieh, Y.K., Wang, Y.F., Zhang, J., Wan, S. (2020). Impact of the COVID-19 event on air quality in central China. Aerosol Air Qual. Res. 20, 915-929. https://doi.org/10.420 9/aaqr.2020.04.0150

Yoo, J.H. (2020). The fight against the 2019-nCoV outbreak: an arduous march has just begun. J. Korean Med. Sci. 35, e56. https://doi.org/10.3346/jkms.2020.35.e56

Zalakeviciute, R., Vasquez, R., Bayas, D., Buenano, A., Mejia, D., Zegarra, R., Diaz, A., Lamb, B. (2020). Drastic improvements in air quality in Ecuador during the COVID-19 outbreak. Aerosol Air Qual. Res. 20, 1783-1792. https://doi.org/10.4209/aaqr.2020.05.0254

Zhou, P., Yang, X.L., Wang, X.G., Hu, B., Zhang, L., Zhang, W., Si, H.R., Zhu, Y., Li, B., Huang, C.L., Chen, H.D., Chen, J., Luo, Y., Guo, H., Jiang, R.D., Liu, M.Q., Chen, Y., Shen, X.R., Wang, X., Zheng, X.S., ... Shi, Z.L. (2020). Discovery of a novel coronavirus associated with the recent pneumonia outbreak in humans and its potential bat origin. bioRxiv 2020.01.22.914952. https://doi.org/1 0.1101/2020.01.22.914952 